Louisiana State University LSU Digital Commons

Faculty Publications

Department of Geography \& Anthropology

1994

\title{
Intensive wetland agriculture in Mesoamerica: Space, time, and form
}

Andrew Sluyter

Louisiana State University, asluyter@lsu.edu

Follow this and additional works at: http://digitalcommons.lsu.edu/geoanth_pubs

\section{Recommended Citation}

Sluyter, Andrew, "Intensive wetland agriculture in Mesoamerica: Space, time, and form" (1994). Faculty Publications. 64. http://digitalcommons.lsu.edu/geoanth_pubs/64

This Article is brought to you for free and open access by the Department of Geography \& Anthropology at LSU Digital Commons. It has been accepted for inclusion in Faculty Publications by an authorized administrator of LSU Digital Commons. For more information, please contact gcoste1@lsu.edu. 


\title{
Intensive Wetland Agriculture in Mesoamerica: Space, Time, and Form
}

\author{
Andrew Sluyter
}

Department of Geography, The University of Texas at Austin

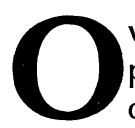

ver the past four decades, geographers have led the effort to better understand Prehispanic, intensive wetland agriculture in Mesoamerica (Siemens 1992; Siemens and Puleston 1972; Turner and Harrison 1983; West and Armillas 1950; Wilken 1969). Their research and that of scholars in allied disciplines has increased our knowledge of past landscapes and human ecologies (Sluyter and Siemens 1992), of the relationships between agricultural and social processes (Scarborough 1983a), and of the viability of alternatives to industrial agriculture (Chapin 1988; Gómez-Pompa 1978). In the time since Denevan (1980a; 1982) and Turner (1983a) last reviewed this literature, however, a great deal of new information has accumulated, and it invites a spatial-temporal analysis that addresses the central themes that have emerged and that serves as a point of departure for further investigation. ${ }^{1}$

This paper focuses on four broad themes reflective of the diversity of scholars involved in the investigation of Mesoamerican landscapes and human paleoecologies. The first of these themes assesses the role of intensive wetland agriculture in the emergence of sedentism, urbanism, statism, and anthropic environmental change. The second explores the interrelationship between intensive wetland agriculture and other agroecosystems, both intensive (terracing and canal irrigation) and extensive (wetland and dryland shifting cultivation). The third focuses on wetland agriculture's ecological parameters, i.e., morphometries, functions, crops, construction techniques, and environments. And the fourth addresses attempts to reconcile the touted productivity and sustainability of intensive wetland agriculture with its now largely vestigial expression. These themes, reflective of the complex processes of ancient Mesoamerica's ecology, quite necessarily are interrelated.

\section{Terms and Methods}

"Mesoamerica" has its time and space (Kirchhoff 1943; Porter Weaver 1981). In time, Mesoamerica refers to the period before Spaniards and Native Americans intersected ca. A.D. 1520. During this Prehispanic period, Mesoamerica became one of two regions of the New World that contained urbanized states-the other being Andean America. In space, Mesoamerica encompassed what is today southern Mexico, Guatemala, Belize, EI Salvador, and parts of Honduras, Nicaragua, and Costa Rica (Figure 1). Nonurban peoples bounded the region on the north and south. In a succession of Prehispanic periods, the OImec, Zapotec, Teotihuacán, Maya, Toltec, and Aztec peoples dominated various subregions of Mesoamerica. These peoples built cities, wrote books, and practiced astronomy, but above all they were farmers-distinguished by their development of intensive wetland agriculture, canal irrigation, and terracing.

"Intensive wetland agriculture" goes by various names: raised fields, ridged fields, ditched fields, camellones, platform fields, chinampas, island fields, island beds, drained fields, ditched/drained fields, channelized fields, and mounded fields (Denevan 1980b; Denevan and Turner 1974; Jacob 1992; Mathewson 1985; Vasey 1983). Whatever the name, this form of agriculture occurs in various contexts: along streams, in lake basins, and at springs. It likewise reflects various construction techniques: ditching into the natural surface, mounding above the natural surface, or both. But in all cases, and despite varying circum- 


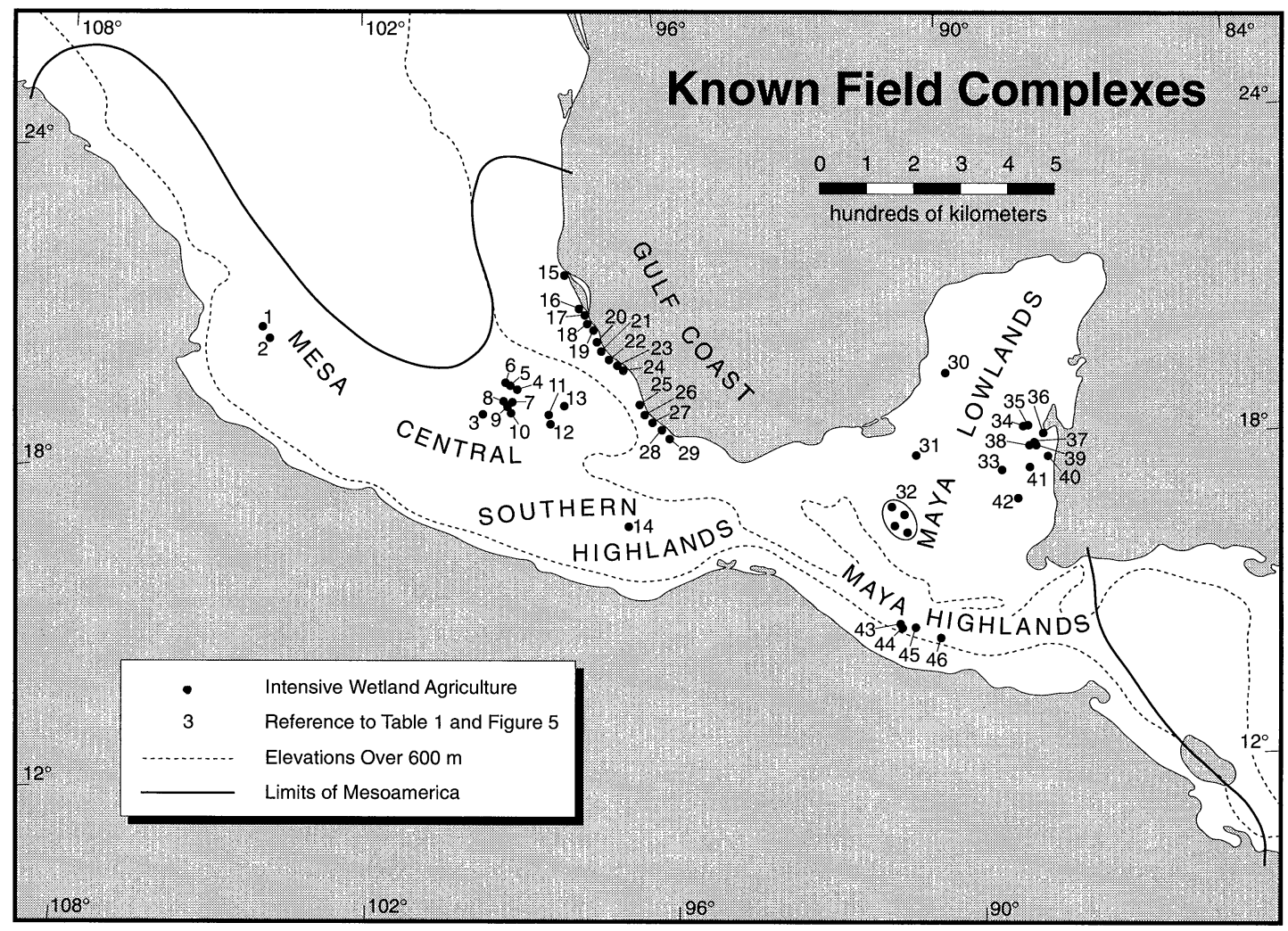

Figure 1. Locations of known intensive wetland agriculture. Sources: Table 1; Base map: Porter Weaver 1981: Map 1.

stances, its purpose seems to have been the same-to regulate soil moisture in the root zone and to maintain a nutrient sump in the canals which farmers periodically might apply to their field surfaces. Also in all cases, this agricultural system was contingent upon water tables at the soil surface for at least part of the year. In seasonally dry environments, farmers accelerated drainage as the water table fell at the end of the wet season, and then retained water in the canals for splash and subirigation during the ensuing dry season, possibly also planting crops in the bottoms of the drier canals. Other farmers lowered a perennially high water table or raised planting surfaces above the water surface. In all cases, farmers took advantage of wetlands by adjusting the relative elevations of the root zone and the water table to maintain the degree of soil moisture most advantageous for crop growth; they accord- ingly intensified production by investing in an infrastructure that increased yields and decreased risks. This commonality suggests "intensive wetland agriculture" as a generic term which subsumes a wide variety of field types, modes of construction, and functions peculiar to specific contexts.

Morphometrically, intensive wetland fields vary widely (Figures 2, 3, 4). Three morphological aspects are pertinent: 1) profile, or the cross section along the short axis of fields and intervening canals; 2) shape, or the plan of individual fields within a complex; and 3) pattern, or the overall plan of a field-canal complex (Denevan 1970; Mathewson 1985). Metrical variation adds further complexity. While canal width, field width, and field length are basic, amplitude, i.e., the vertical distance between field surface and canal bottom, and frequency, i.e., the number of field-canal pairs 


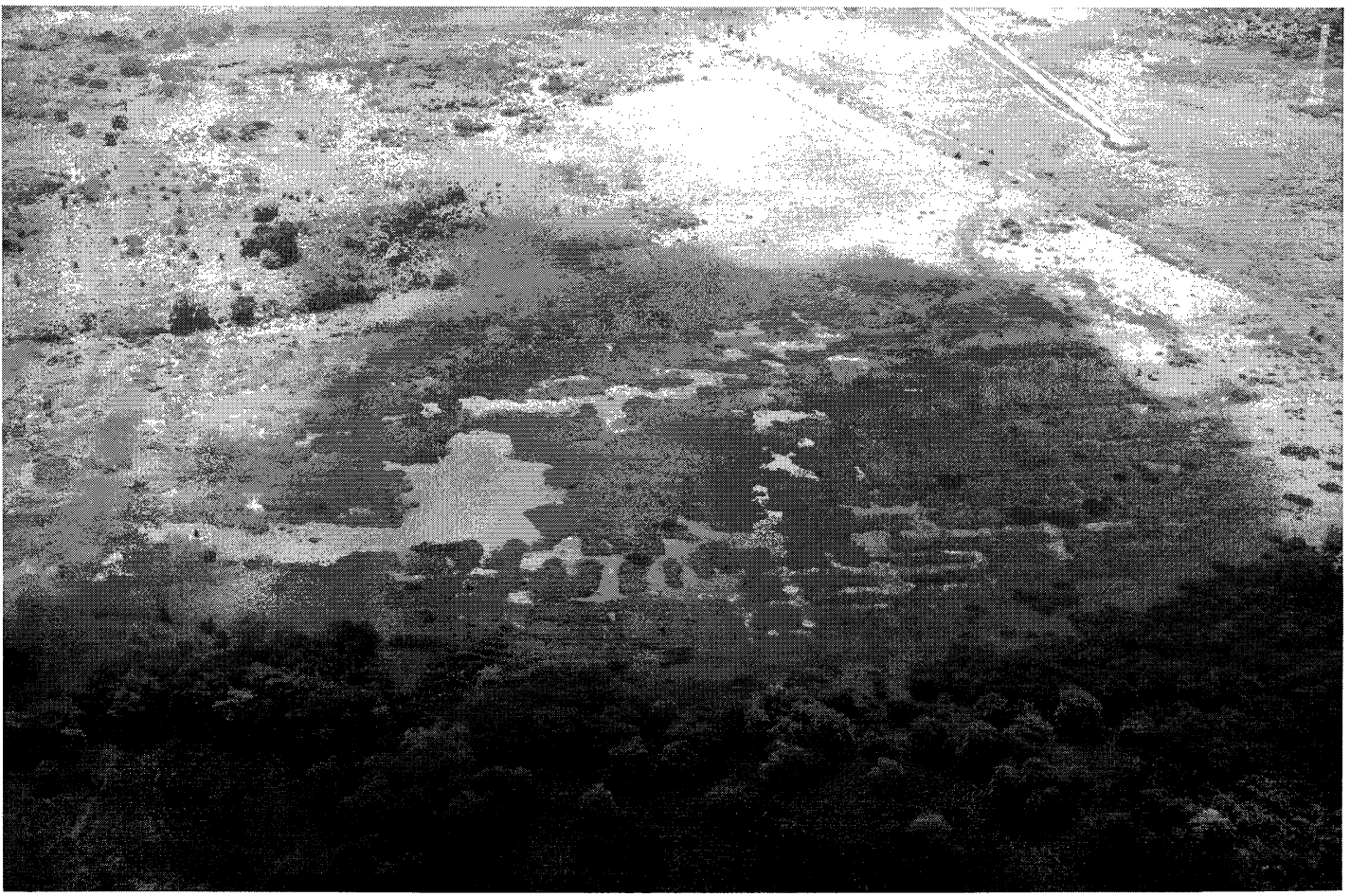

Figure 2. A vestige of Prehispanic intensive wetland agriculture at Río San Juan in the Gulf Coast subregion. For location, see Figure 1.

over a given horizontal distance, are related variables.

Extensive agriculture also occurs in Mesoamerican wetlands today, and doubtless it did so in Prehispanic times. The marceño of Tabasco, Mexico, a flood-recessional cultivation technique, offers a case in point (OrozcoSegovia and Gliessman 1979). But extensive agriculture of this sort is ephemeral, requires little investment in field infrastructure, and effects little in the way of enduring landscape modifications. Researchers have relied on ethnographic and historic analogs and on ecological models. Moreover, extensive agricultural systems that depended on the natural soil moisture regime entailed high risk of crop failure and low yield that made them unlikely candidates to support dense populations.

For these reasons of evidence and interpretation, this paper focuses on intensive wetland agriculture-hereafter termed "wetland agricul- ture" or "wetland fields." A review of the literature (Table 1$)^{2}$ provides the basis for a spatialtemporal analysis that employs a chronological diagram (Figure 5) and a series of maps (see following figures) to identify relationships among three variables: 1) distribution; 2) hectareage; and 3) morphometry. Five distinctive subregions defined by physiography (West 1964) and culture (Porter Weaver 1981) frame the spatial analysis (Figure 1 and Table 1): 1) the Mesa Central; 2) the Southern Highlands; 3) the Gulf Coast; 4) the Maya Lowlands; and 5) the Maya Highlands. Three periods frame the temporal analysis (Figure 5): 1) Preclassic (2500 B.C. to A.D. 1); 2) Classic (A.D. 1 to 900 ); and 3) Postclassic (A.D. 900 to 1521). These periods signal ecological transformations: as a sketch, the widespread emergence of agricultural sedentism during the Preclassic, urbanism during the Classic, and large states during the Postclassic (Porter Weaver 1981). The database 


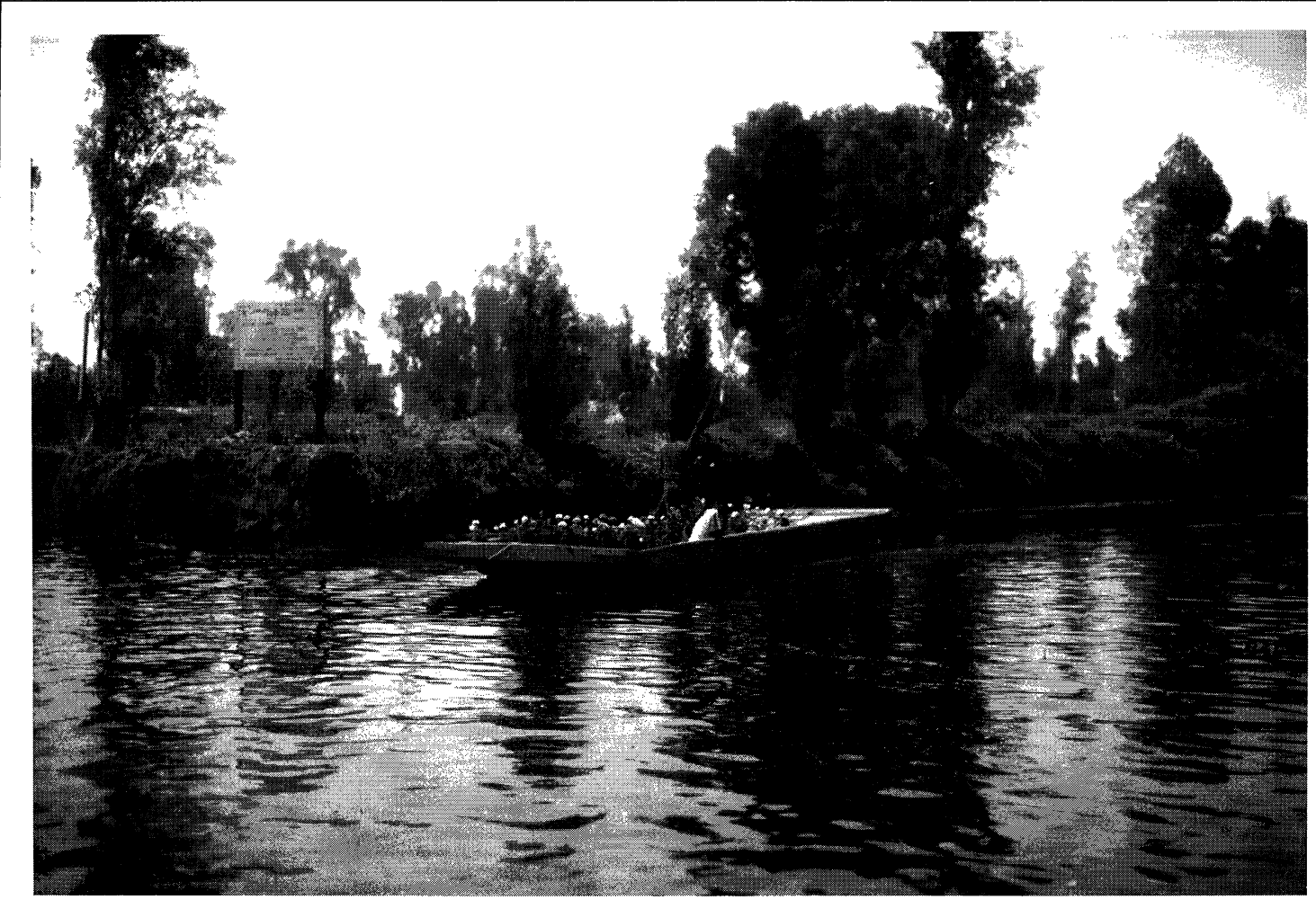

Figure 3. Extant intensive wetland agriculture at Xochimilco in the Mesa Central subregion. For location, see Figure 1.

relies on the primary researchers' conclusions, even when drawn on scant data and relative rather than absolute dating methods. In some cases, measurements of diagrams, maps, and photographs rather than explicit statements yield the hectareage and morphometric data.

\section{Regional Patterns}

\section{The Mesa Central}

The Mesa Central is the southern portion of the Mexican Altiplano, a high-altitude plateau interrupted by volcanic ranges and basins. The generally subhumid and temperate climate has a wet-summer, dry-winter precipitation regime. Owing to the winter dry season and to frosts, rainfed agriculture is only possible during the summer. Intensive wetland fields occupy a series of volcanic basins that stretch in an arc from northwest to southeast (Figure 1).
Early researchers focused their attention on chinampas, the prominent wetland fields in the Xochimilco-Chalco subbasin (Humboldt 1966; Nuttall 1925. Santamaría 1912; Schilling 1938). Since the 1940s, when investigators began to apply techniques to estimate chronologies and hectareages (Armillas 1971; Avila López 1991; Serra Puche 1988; West and Armillas 1950), research has accented the role of chinampas as the subsistence base for the Aztec and, perhaps, Teotihuacán states. In addition, a series of related studies has examined extant chinampas, often emphasizing their productivity and sustainability as a model for current development efforts (Moriarty 1968; Gómez-Pompa 1978; García Mora 1979; Rojas Rabiela 1983a; 1991; Wilken 1985; Niederberger 1987; López Ríos 1988).

Other basins in the Mesa Central have elicited less attention. Wilken (1969) has studied extant fields in the Puebla-Tlaxcala Basin, but their changing spatial and temporal distribu- 


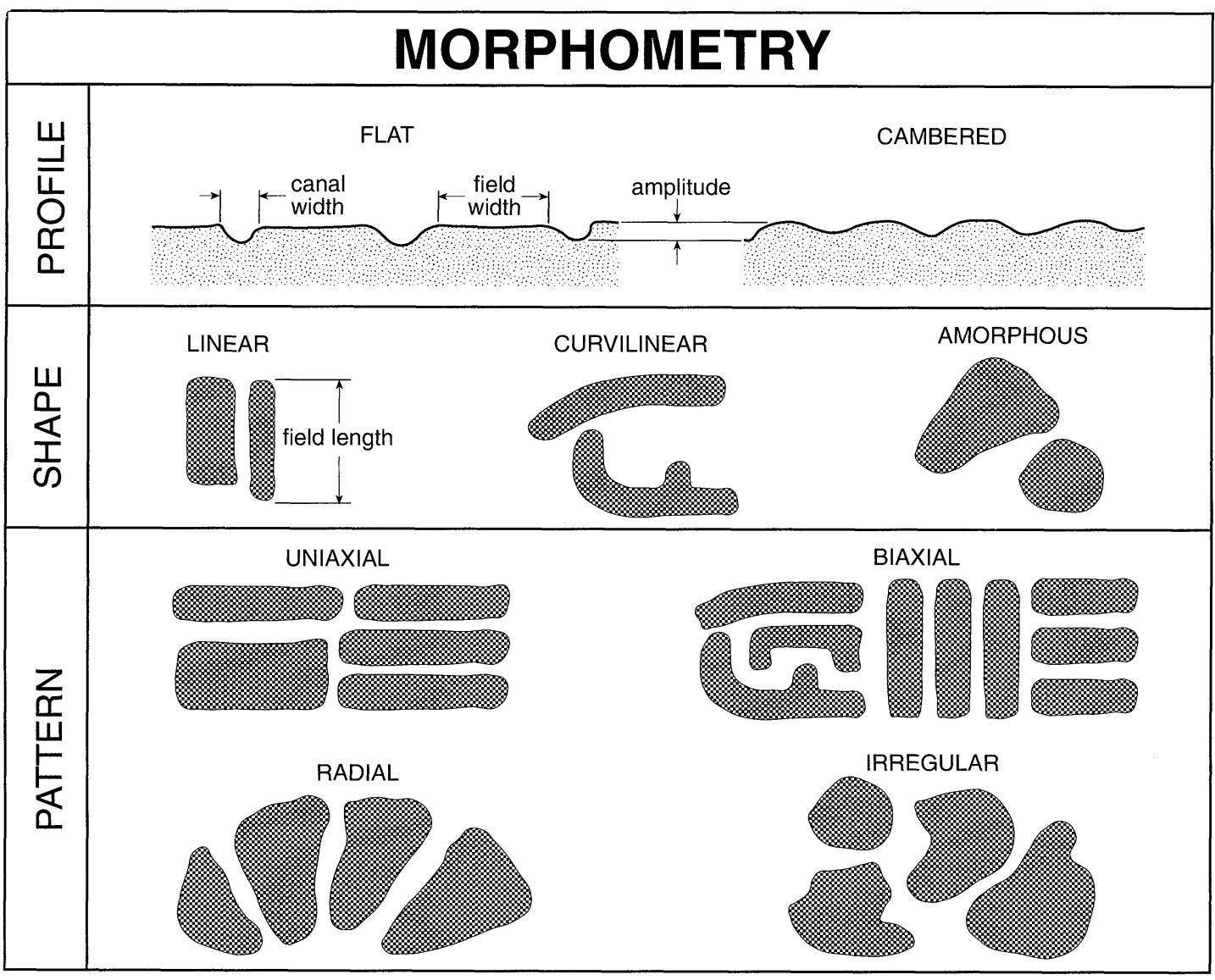

Figure 4. Morphometry of intensive wetland agriculture.

tions remain little known (García Cook 1985) save for the fields at Amalucan (Fowler 1987). Both extant and vestigial fields in the Huamantla and Toluca basins have received but little attention (Sugiura Yamamoto and Serra Puche 1983). And while Weigand (1993) has directed attention to large hectareages of fields in the Etzatlán and Teuchitlán basins near Guadalajara, research there remains at an early stage.

\section{The Southern Highlands}

The Southern Highlands, a series of highly dissected mountain ranges located between the Balsas Depression and the Isthmus of Tehuantepec, yields meager evidence of intensively cultivated wetlands. The generally temperate climate has a wet-summer, drywinter precipitation regime. The only known instance of intensive wetland fields occurs at San Antonio Arrazola in the Valley of Oaxaca (Wilken 1969), one of the few large expanses of alluvium in the Southern Highlands (Figure 1). While these extant fields remain unstudied, their proximity to Monte Albán-the dominant Classic-period settlement in this subregion (Porter Weaver 1981)-hints at the possibility of Prehispanic origins.

\section{The Gulf Coast}

The evidence of intensive wetland agriculture is more plentiful in the Gulf Coast, a plain that fronts on the Gulf of Mexico. The generally 
Table 1. Post-1940 Sources Pertaining to Intensive Wetland Agriculture in Mesoamerica.

\begin{tabular}{|c|c|c|}
\hline $\begin{array}{l}\text { Location } \\
\text { Number }\end{array}$ & Location & Sources \\
\hline & & Mesa Central \\
\hline 1 & Etzatlán Basin & Weigand 1974; 1991; 1993 \\
\hline 2 & Teuchitlán Basin & Weigand $1974 ; 1991 ; 1993$ \\
\hline 3 & Toluca Basin & $\begin{array}{l}\text { West and Armillas 1950; Sugiura Yamamoto and Serra Puche } \\
\text { 1983; personal observation, } 1992\end{array}$ \\
\hline $4-10$ & Basin of Mexico & Palerm 1955; 1973; Rojas Rabiela et al. 1974 \\
\hline 4 & Teotihuacán & $\begin{array}{l}\text { Sanders et al. 1970; 1975; Millon 1973; Sanders 1976a; } \\
\text { Sanders et al. } 1979\end{array}$ \\
\hline 5 & Zumpango & Palerm 1973 \\
\hline 6 & Xaltocan & $\begin{array}{l}\text { West and Armillas 1950; Palerm 1973; Brumfiel and Frederick } \\
\text { 1992; Nichols and Frederick } 1993\end{array}$ \\
\hline 7 & Eastern Texcoco & Apenes 1943; Noguera 1943 \\
\hline 8 & Tenochtitlán & Calnek 1972; 1973; 1976; 1978; Palerm 1973 \\
\hline 9 & Iztapalapa & Palerm 1973; Avila López 1991 \\
\hline 10 & Xochimilco-Chalco & $\begin{array}{l}\text { Coe 1964; Armillas 1971; 1987; Palerm 1973; Tolstoy } 1975 ; \\
\text { Parsons 1976; 1991; Tolstoy et al. 1977; Smith and Tolstoy } \\
\text { 1981; Parsons et al. 1982; 1985; McClung de Tapia et al. } \\
\text { 1986; Serra Puche } 1988 ; 1990\end{array}$ \\
\hline $11-12$ & Puebla-Tlaxcala Basin & Wilken 1969 \\
\hline 11 & Puebla-Tlaxcala & $\begin{array}{l}\text { Wilken 1969; 1970; 1987; García Cook 1974; 1981; 1985; } \\
\text { 1986; Abascal and García Cook 1975; Prem 1975; Abascal } \\
\text { et al. 1976; García Cook and Merino Carrión } 1990\end{array}$ \\
\hline 12 & Amalucan & Fowler 1969; 1978; 1987; Woods and Fowler 1989 \\
\hline 13 & Huamantla Basin & personal observation, 1992 \\
\hline & & Southern Highlands \\
\hline 14 & San Antonio Arrazola & Wilken 1969 \\
\hline & & Gulf Coast \\
\hline 15 & Estero de la Llave & Siemens 1982a; 1983a; 1989 \\
\hline 16 & Estero Tancochín & Siemens 1982a; 1983a; 1989 \\
\hline 17 & $\begin{array}{l}\text { Río Metropolitano- } \\
\text { Estero Milpillas }\end{array}$ & Siemens 1982a; 1983a; 1989; Wilkerson 1983 \\
\hline 18 & Estero de Oro Verde & Siemens 1982a; 1983a; 1989 \\
\hline 19 & Río Tuxpan & Wilkerson 1983 \\
\hline 20 & Río Cazones & Wilkerson 1983 \\
\hline 21 & Río Tecolutla & Wilkerson 1980; 1983; Siemens 1982a; 1983b; 1989 \\
\hline 22 & Estero de Tres Bocas & $\begin{array}{l}\text { Schmidt 1977; Siemens 1982a; 1983b; 1985; 1989; } \\
\quad \text { Wilkerson } 1983\end{array}$ \\
\hline 23 & Río Nautla & Siemens 1982a; 1983a; 1989; Wilkerson 1983 \\
\hline 24 & Río Colipa & Siemens 1982a; 1983a; 1989; Wilkerson 1983 \\
\hline
\end{tabular}

humid and hot climate, with a wet-summer, dry-winter precipitation regime, limits rainfed agriculture, particularly in central Veracruz (Figure 1, locations 25-28) where the dry season is most intense. Vestigial fields occur in backswamps near the mouths of streams that head in the highlands to the west. Schmidt (1977) first noted fields at Estero de Tres Bocas, and Wilkerson (1983), Stark (1990a), and Siemens $(1980 ; 1992)$ have followed with further investigations. Nonetheless, these fields remain largely unstudied, save for those at Estero de Tres Bocas, Río Tecolutla, and Río San Juan.

\section{The Maya Lowlands}

The climate of this low-elevation limestone peninsula-punctuated by karst landforms such as bajos (poljes) and cenotes (collapsed dolines)-generally is hot and humid, the winter dry season longest in the north and absent in 
Table 1. continued.

\begin{tabular}{|c|c|c|}
\hline $\begin{array}{l}\text { Location } \\
\text { Number }^{\text {a }}\end{array}$ & Location & Sources \\
\hline & & Gulf Coast \\
\hline 25 & Arroyo Naranjillo & $\begin{array}{l}\text { Siemens } 1979 ; 1980 ; 1983 b ; 1983 c ; 1989 ; \text { Sluyter and } \\
\text { Siemens } 1992\end{array}$ \\
\hline 26 & Río San Juan & $\begin{array}{l}\text { Siemens 1979; 1980; 1983b; 1983c; 1989; 1992; Siemens } \\
\quad \text { et al. 1988; Hebda et al. } 1991\end{array}$ \\
\hline 27 & Río Jamapa & Siemens $1979 ; 1980 ; 1983 b ; 1983 c ; 1989$ \\
\hline 28 & Laguna Mandinga & Siemens 1979; 1980; 1983b; 1983c; 1989 \\
\hline 29 & La Mixtequilla & Stark 1977; 1990a; 1990b \\
\hline & & Maya Lowlands \\
\hline & & $\begin{array}{l}\text { Adams 1980; 1982; 1983; 1991; 1993; Adams et al. 1981; } \\
\text { 1990; Pope and Dahlin 1989; 1993; Dunning et al. 1991; } \\
\text { Dunning n.d. }\end{array}$ \\
\hline 30 & Edzná & $\begin{array}{l}\text { Matheny } 1976 ; 1978 ; 1982 ; \text { Mathney and Gurr 1983; } \\
\text { Mathney et al. } 1983\end{array}$ \\
\hline 31 & Río Candelaria & Siemens and Puleston 1972; Siemens 1989 \\
\hline 32 & Río Usumacinta group & Siemens and Puleston 1972; Siemens 1989 \\
\hline 33 & Río Azul & $\begin{array}{l}\text { Adams 1984; 1990; Black and Suhler 1986; Black 1987; } \\
\text { Culbert et al. } 1990\end{array}$ \\
\hline 34 & Bajo de Morocoy & $\begin{array}{l}\text { Turner 1974; 1978a; 1978b; Harrison 1977; 1978; 1982; } \\
\quad \text { Turner and Harrison 1978; Siemens 1978; Gliessman et al. } \\
\text { 1983; } 1985\end{array}$ \\
\hline 35 & Bajo Acatuch & $\begin{array}{l}\text { Harrison 1977; 1978; 1982; Siemens 1978; Turner and } \\
\quad \text { Harrison } 1978\end{array}$ \\
\hline $36-39$ & Northern Belize & Siemens 1982b; 1983b \\
\hline 36 & Cerros & $\begin{array}{l}\text { Freidel and Scarborough 1982; Scarborough 1983a; 1983b; } \\
\text { 1986; Crane } 1986\end{array}$ \\
\hline 37 & Nohmul & Hammond $1983 ; 1985 ;$ Hammond et al. $1985 ; 1987$ \\
\hline 38 & Albion Island & $\begin{array}{l}\text { Olson et al. 1975; Olson 1977; Puleston 1977a; 1977b; 1979; } \\
\text { Siemens 1977; 1982b; 1983b; Antoine et al. 1982; Bloom } \\
\text { et al. 1983; 1985; Pohl 1990; Pohl et al. } 1990\end{array}$ \\
\hline 39 & Pulltrouser Swamp & Turner and Harrison 1981; 1983; Turner 1986; Harrison 1990 \\
\hline 40 & Cobweb Swamp & Jacob 1992 \\
\hline 41 & Lamanai & $\begin{array}{l}\text { Lambert and Arnason 1983; Lambert et al. 1984; Lambert } \\
1985\end{array}$ \\
\hline 42 & Norlands Farm & Kirke 1980 \\
\hline & & Maya Highlands \\
\hline 43 & Quezaltenango & Wilken $1971 ; 1987$ \\
\hline 44 & Almolonga & Wilken 1971; 1987 \\
\hline 45 & Panajachel & Mathewson 1984; Wilken 1971; 1987 \\
\hline 46 & Antigua & Wilken $1971 ; 1987$ \\
\hline
\end{tabular}

alocation numbers cross-reference to Figures 1 and 5-14.

the south. Vestigial wetland fields occur in bajos and in the backswamps of streams along the western and eastern flanks of the peninsula (Figure 1).

Owing to scholarly fascination with the Maya civilization that emerged, atypically, in a humid tropical lowland (Mathewson 1977; Turner 1986) and that offers a diachronic perspective on such global-change processes as deforestation, interpretation of several aspects of the data remains controversial. The main debates turn on the spatial-temporal distribution of wet- land agriculture in the Maya Lowlands and the relative significance of these intensive agroecosystems (vis-á-vis shifting agriculture) for the emergence and decline of urbanism and statism and of corollary environmental change during the Classic period. Siemens and Puleston (1972) first documented wetland agriculture in backswamps along the Río Candelaria on the western flank of the Maya Lowlands, thereby supporting a precocious hypothesis (Palerm and Wolf 1957:28) and challenging the validity of the prevailing shift- 


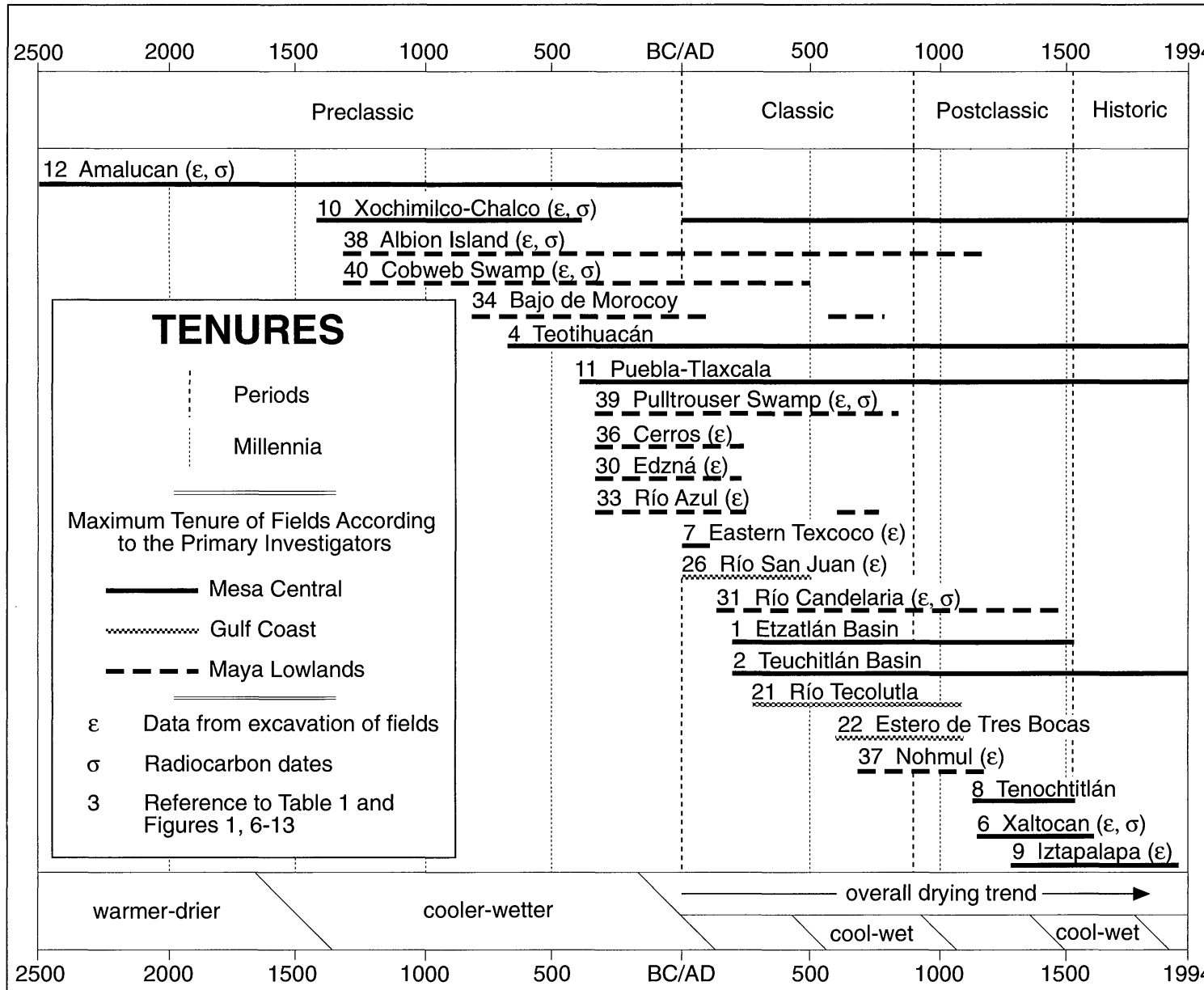

Figure 5. Tenures of intensive wetland agriculture for locations with chronological data. Sources: Table 1; for climate, see text; for periodization, see Porter Weaver 1981: back endpapers.

ing-cultivation paradigm. Problematically, however, the dominant Mayan settlements and the highest population densities occurred in the core of the karstic peninsula, far from the major surface streams and surrounded by seasonally wet bajos (Puleston 1978; 1979).

In an effort to test the hypothesis that wetland fields also occurred in bajos in the environs of Tikal and other dominant settlements, Adams and colleagues employed airborne synthetic aperture radar. They estimated that the southern half of the Maya Lowlands contains some $125,000-250,000$ ha of vestigial field complexes (Adams 1980; 1982; Adams et al. 1981). Subsequent research has not sustained these high estimates (Pope and Dahlin 1989; 1993; Dunning n.d.; Dunning et al. 1991); nor are sizable hectareages evident anywhere in the core of the peninsula (Dahlin 1979; Dahlin et al. 1980; but see also Adams et al. 1990; Adams 1991; 1993).

Other researchers, meanwhile, documented wetland fields in bajos, as well as along streams, on both flanks of the peninsula. Vestigial wetland fields were initially identified through low-altitude aerial photography and ground survey (Siemens 1982b; Turner 1974), and subsequent excavations (Gliessman et al. 1983; Pohl 1990; Turner and Harrison 1981) refuted protests that ground patterns in bajos 
were naturally forming gilgai (Puleston 1978; Sanders 1979). Harrison's claim (1977) that Bajo Acatuch contains the largest extent of field vestiges in Mesoamerica remains unsubstantiated, however. While Harrison maintains that his published photographs "clearly show broad patterns of grid-like variation in the vegetation ... [which] . . compares favorably with ... [that] shown in photos published by Siemens and Puleston [1972] . . . and identified by them as various forms of raised fields [i.e., intensive wetland fields]" (Harrison 1977:477), such distinctive patterning is not readily evident. The equivocal nature of the evidence from these aerial photographs and the lack of ground survey and excavation notwithstanding, Harrison estimates some 24,610 ha of canals and planting surfaces for Bajo Acatuch (Harrison n.d., personal communication, as cited in Denevan 1982:Table 1). Even granting their existence, a dot planimeter measurement of Harrison's map reduces the figure to a maximum of 18,400 ha (1978:Figure 13.1), and Turner (1974:121) reduces it to just 12,000 ha.

\section{The Maya Highlands}

The Maya Highlands offer much less evidence of wetland fields than do the adjoining lowlands. In this series of highly dissected mountain ranges lying between the Maya Lowlands and the Pacific coastal plain, the climate generally is temperate with a short winter dry season. The known wetland fields are located in a series of volcanic basins near the settlements of Quezaltenango, Almolonga, Antigua (Wilken 1971), and Panajachel (Mathewson 1984). The last are "chinampa-like tablones," a regionally specific form of irrigation terrace. The antiquity of the Maya Highland fields remains uncertain, but both Wilken (1971) and Mathewson (1984) have suggested Prehispanic origins.

\section{Analysis: Distribution, Hectareage, Morphometry}

\section{Distribution}

Figure 1 maps known instances of intensive wetland fields. Figure 5 displays the tenures of the 22 cases with chronological data; see also Figures 6-10. In eight of these 22 cases, the chronologies are based on nothing more than surface ceramics and the chronologies of nearby (and presumably contemporaneous) settlements. The remaining 14 cases are dated through excavation of the fields themselves, with 7 of these employing radiocarbon dating. The most rigorous chronologies pertain to Etzatlán, Teuchitlán, Xaltocan, Tenochtitlán, Iztapalapa, Xochimilco-Chalco, Amalucan, Estero de Tres Bocas, Río San Juan, Edzná, Río Candelaria, Cerros, Nohmul, Albion Island, and Pulltrouser Swamp. But that rigor is relative owing to the difficulties of dating agricultural features. Even some of these "rigorous" chronologies span long periods when fields might have been in use; such is the case for Etzatlán, Teuchitlán, Xochilmilco-Chalco, Amalucan, Río Candelaria, Albion Island, and Pulltrouser Swamp. Most provisional are the chronologies of the fields at Teotihuacán, Eastern Texcoco, Puebla-Tlaxcala, Río Tecolutla, Río Azul, Bajo de Morocoy, and Cobweb Swamp, while the chronologies of the fields in the Southern Highlands and the Maya Highlands are unknown.

The spatial distribution of fields reveals the Mesa Central, the Maya Lowlands, and the Gulf Coast as regional nodes of wetland agriculture (Figure 1). Significantly, these subregions also served as the loci for the emergence of Mesoamerican sedentism, urbanism, statism, and corollary environmental changes. However, while in the Mesa Central the densest distribution of fields occurs in the environs of the dominant settlements, that is not the case in the other two subregions. Vestigial fields are located some distance from the dominant settlements of the Olmec along the Gulf Coast and Maya in their Lowlands (Figures $6-8$ ). This lack of association may reflect the need for further research. The recent identification of vestigial fields in the Etzatlán and Teuchitlán basins may be a harbinger of future discoveries. More persistent exploration might reveal that fields became buried by sedimentation associated with environmental disturbance around major population nodes. Conversely, the absence could reflect that populations such as the Olmec sustained themselves with extensive agroecosystems alone (Coe and Diehl 1980:144-147).

The temporal distribution of wetland fields 


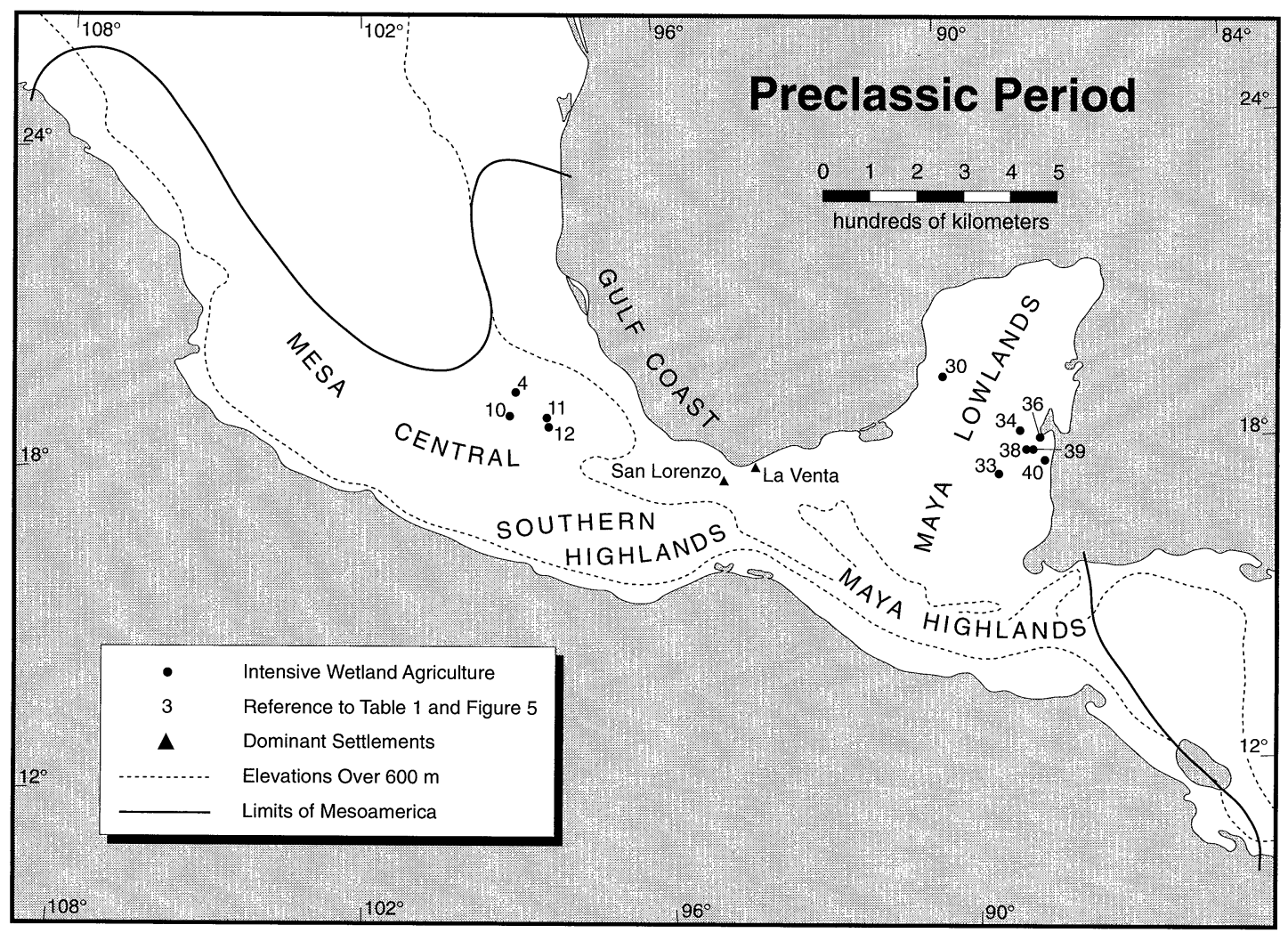

Figure 6. Locations of intensive wetland agriculture and dominant settlements during the Preclassic period (2500 B.C. to A.D. 1) for locations with chronological data. Sources: Table 1; Base map: Porter Weaver 1981: Map 1; for settlement, see Blanton et al. 1981; Hammond 1990; Porter Weaver 1981.

reveals their already widespread use during the Preclassic emergence of agricultural sedentism and incipient urbanism (Figures 5-6). Current evidence suggests that the earliest fields were located in the Mesa Central at Amalucanlending substance to provisional indications of early fields in the Xochimilco-Chalco subbasin, only some $100 \mathrm{~km}$ to the west. The Mesa Central might also have sustained other fields, at Teotihuacán and in the Puebla-Tlaxcala Basin, by the last millennium B.C. The Maya Lowland fields at Albion Island and Cobweb Swamp suggest similarly early origins. Along the Gulf Coast, the as yet limited data indicate that fields may not have been present until the first millennium A.D.

Extant fields are confined to the highlands (Figure 10). While exact figures on the extent of fields in the Maya Highlands and Southern Highlands are lacking, the preponderance of extant fields occur in the Mesa Central. The Basin of Mexico contains a large area of extant chinampas in the Xochimilco-Chalco subbasin and a smaller area of wetland fields at Teotihuacán. The extent of the former is steadily decreasing, however, owing to urban expansion and hydrological changes. For example, the fields at Iztapalapa yielded to urban sprawl in 1981. Large but unspecified areas of extant fields also occur in the Puebla-Tlaxcala Basin, with smaller areas in the Teuchitlan, Toluca, and Huamantla basins.

Extant fields are absent from the lowlands, where only vestiges remain of a once intensively cultivated landscape. Most of these fields suffered abandonment centuries before Euro- 


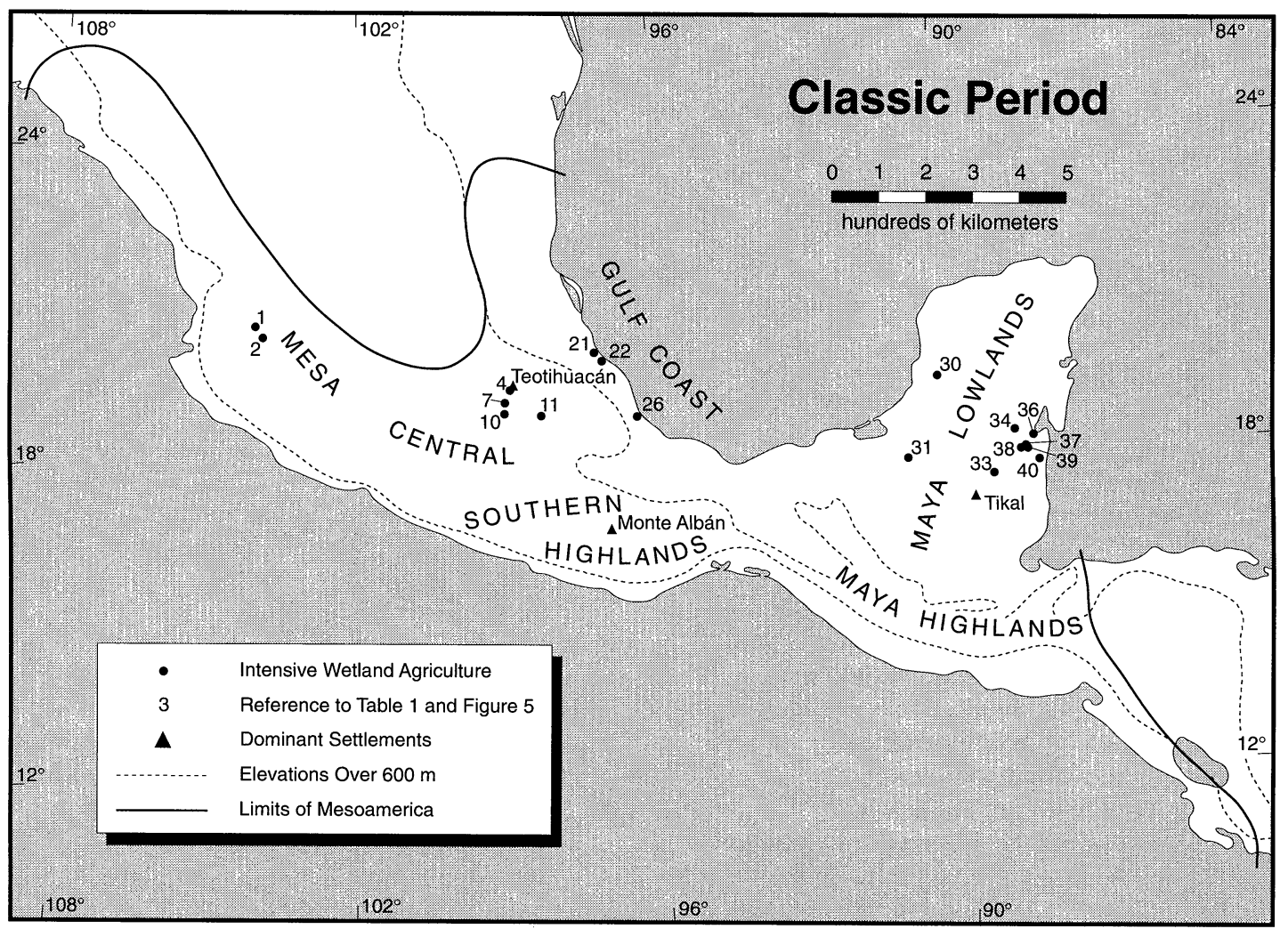

Figure 7. Locations of intensive wetland agriculture and dominant settlements during the Classic period (A.D. 1 to 900 ) for locations with chronological data. Sources: Table 1; Base map: Porter Weaver 1981: Map 1; for settlement, see Blanton et al. 1981; Hammond 1990; Porter Weaver 1981.

peans introduced the Old World diseases that resulted in population declines of as much as 90 percent (Denevan 1992). Only at one site, Río Candelaria, does the timing of field abandonment coincide with European invasion.

The lengthy tenure of wetland agriculture in some subregions-perhaps as long as three millennia in the Basin of Mexico and two millenia in the Maya Lowlands-suggests sustainability and applicability to current development efforts. But that many fields survive only as vestiges (and have been so for centuries) has led some scholars to suggest the opposite: that the nonsustainability of wetland agriculture might have contributed to the late-Classic depopulation of the Maya Lowlands (Atran 1993). If the reasons for the abandonment of these fields remain unclear-whether environmental degradation linked to intensive agriculture, changing cultural context, depopulation, or changing perceptions-so too have been the benefits of reinstating wetland agriculture in lowland regions. These efforts have required high inputs of fertilizers and insecticides in order to achieve acceptable yields (GómezPompa 1978; Gómez-Pompa et al. 1982). However, these results may well follow from the imposition of agroecological models based on practices in extant highland fields upon lowlands which are environmentally, culturally, and economically distinct (Chapin 1988).

Less controversial is the association between intensive wetland agriculture, terracing, and canal irrigation (Figure 11). The conjunction of wetland fields and terracing is evident in the Basin of Mexico, the Puebla-Tlaxcala Basin, the 


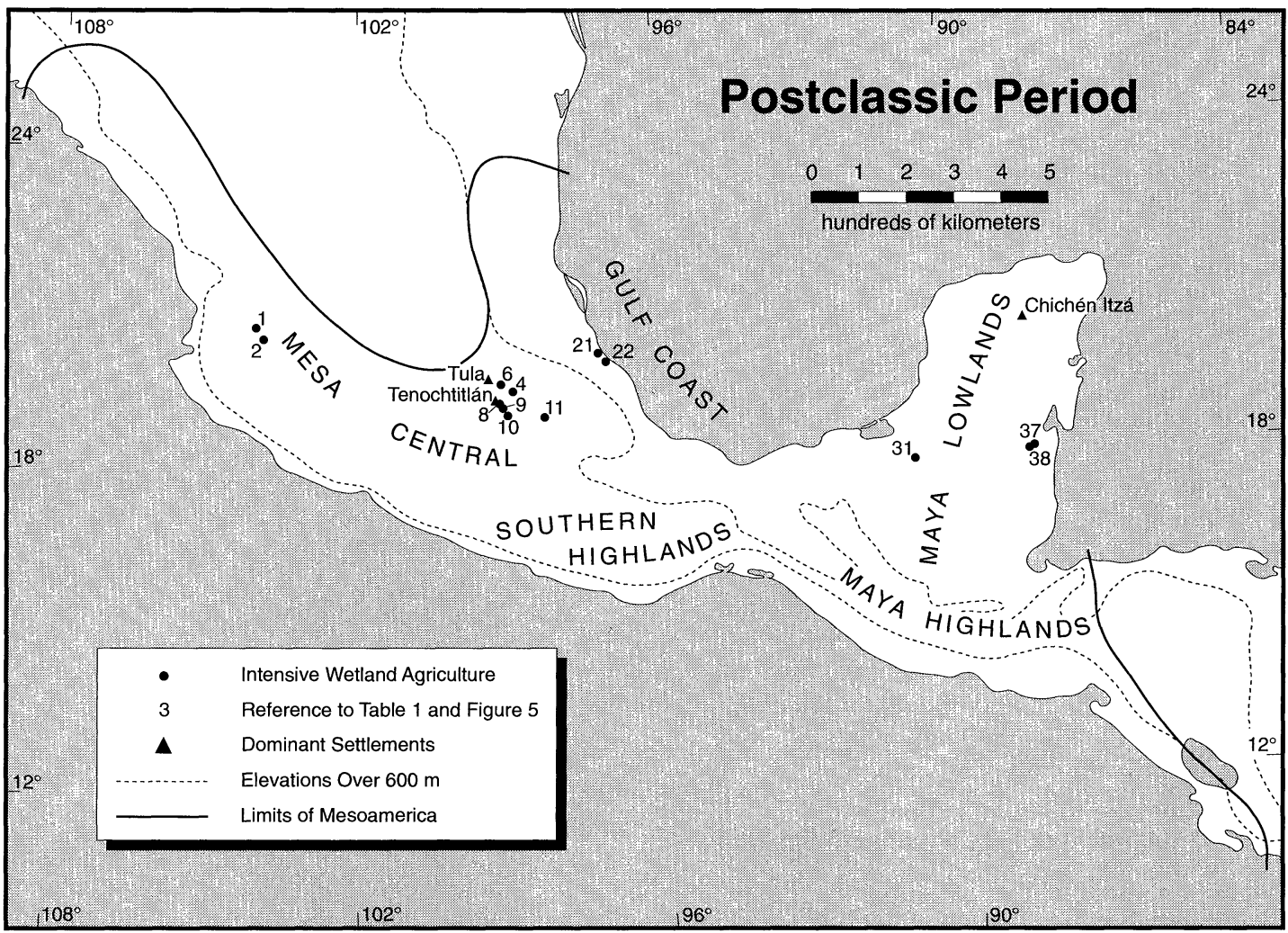

Figure 8. Locations of intensive wetland agriculture and dominant settlements during the Postclassic period (A.D. 900 to 1521) for locations with chronological data. Sources: Table 1; Base map: Porter Weaver 1981: Map 1; for settlement, see Blanton et al. 1981; Hammond 1990; Porter Weaver 1981.

central Gulf Coast, San Antonio Arrazola in the Southern Highlands, Panajachel in the Maya Highlands, and the eastern Maya Lowlands. Canal irrigation is similarly widespread, save in the Maya Lowlands. Although the chronologies for terracing and canal irrigation often are tenuous, both begin as early as the last millennium B.C. (Donkin 1979; Doolittle 1990). In some places, vestigial wetland fields, terraces, and canal irrigation are closely juxtaposed. Along the Arroyo Naranjillo in central Veracruz, for example, sloping-field terraces overlook wetland fields just to the south of a putative canal irrigation system at Zempoala (Doolittle 1990:113-114; Sluyter and Siemens 1992). Yet the contemporaneity of these agroecosystems is uncertain. These vestigial conjunctions may represent either different periods of intensification and disintensification as agricultural emphases shifted between piedmont and backswamp (a temporal interrelationship); or an integrated system of wetland and canal-irrigated fields that provided dry-season crops as complements to the wet-season crops of the terraced fields (a spatial interrelationship). Modern agricultural practice suggests the possibility of more complex ecological interrelationships as, for example, those deployed by some farmers in central Veracruz who employ wetland seedbeds for germinating maize subsequently transplanted to the piedmont at the beginning of the wet season (Siemens 1990). This strategy, in part, advances growth far enough by transplanting time in May to ameliorate the 


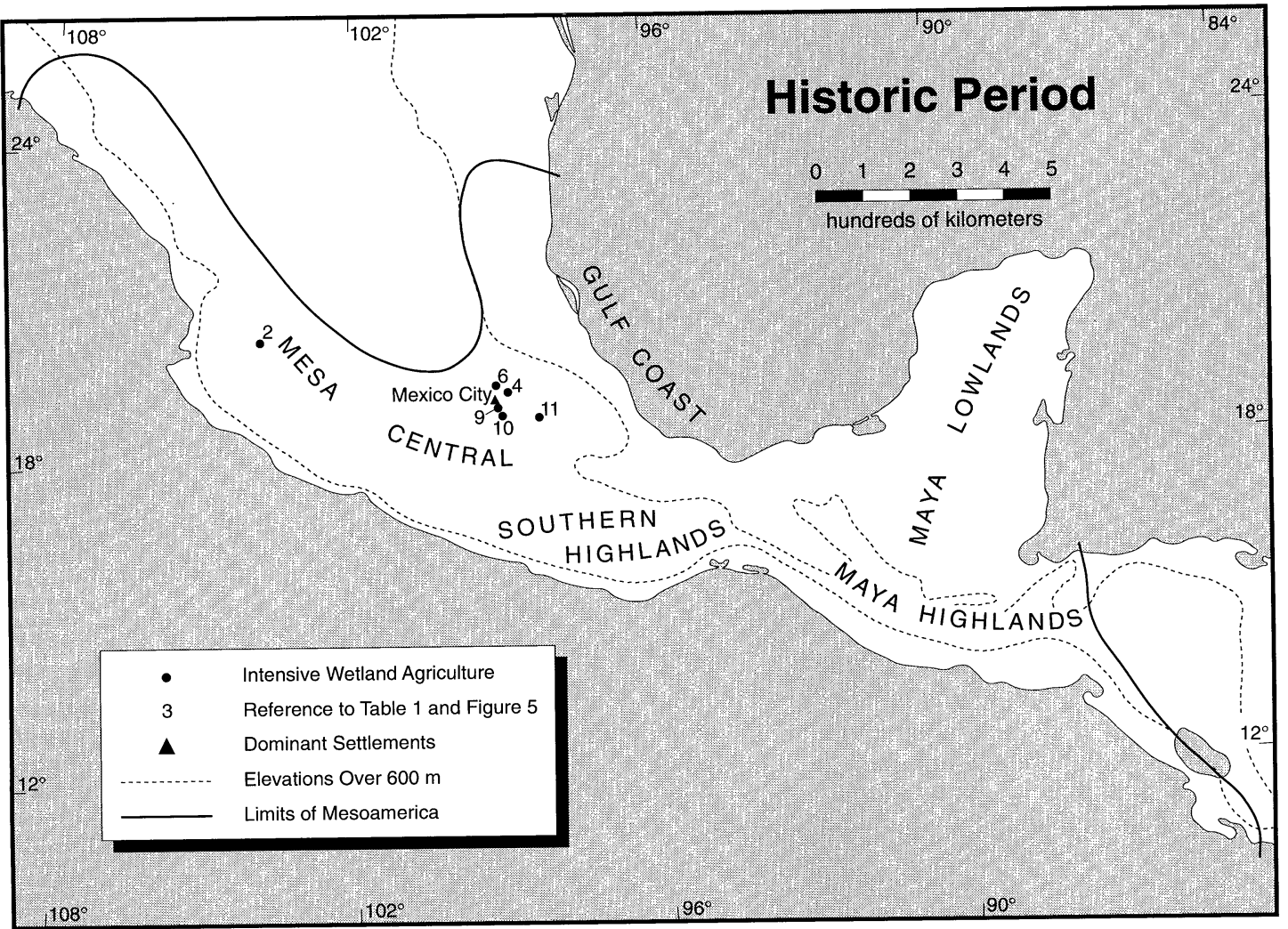

Figure 9. Locations of intensive wetland agriculture and dominant settlements during the Historic period (A.D. 1521 to 1994) for locations with chronological data. Sources: Table 1; Base map: Porter Weaver 1981: Map 1.

worst effects of the canícula, the August dry period, which typically lasts for one to two weeks (Sluyter 1990:58-59).

Similar ecological relationships may have existed between the Xochimilco-Chalco subbasin and the adjacent piedmont (Parsons 1991:34). Also, the wetland fields at Panajachel, though less than 0.1 ha in extent, constitute part of a much larger terrace and canal-irrigation agroecosystem (Mathewson 1984) and suggest ecological interrelationships that may have been even more significant in the past.

\section{Hectareage}

Some of the hectareage estimates (Figure 12) remain tentative and necessitate maximum and minimum figures. Allowing the maximum figures and employing 75 percent as the ratio of field surface to total complex area (see sources in Table 1), the Maya Lowlands account for the largest hectareage of wetland fields-more than 22,900 ha. The Mesa Central follows with some 11,850 ha, but this figure includes neither the Puebla-Tlaxcala fields nor those surrounding the Aztec capital of Tenochtitlán, both of unknown extent. Discounting the still dubious Bajo Acatuch fields, the Maya Lowlands would follow the Mesa Central with 9,100 ha. The Gulf Coast follows both with 1,650 ha in central Veracruz (locations 25-28) and several thousand potential but still unspecified hectares to the north and south. Not many data are available for the Maya Highlands and Southern Highlands but hectareages there seem to be minimal.

The populations such hectareages could 


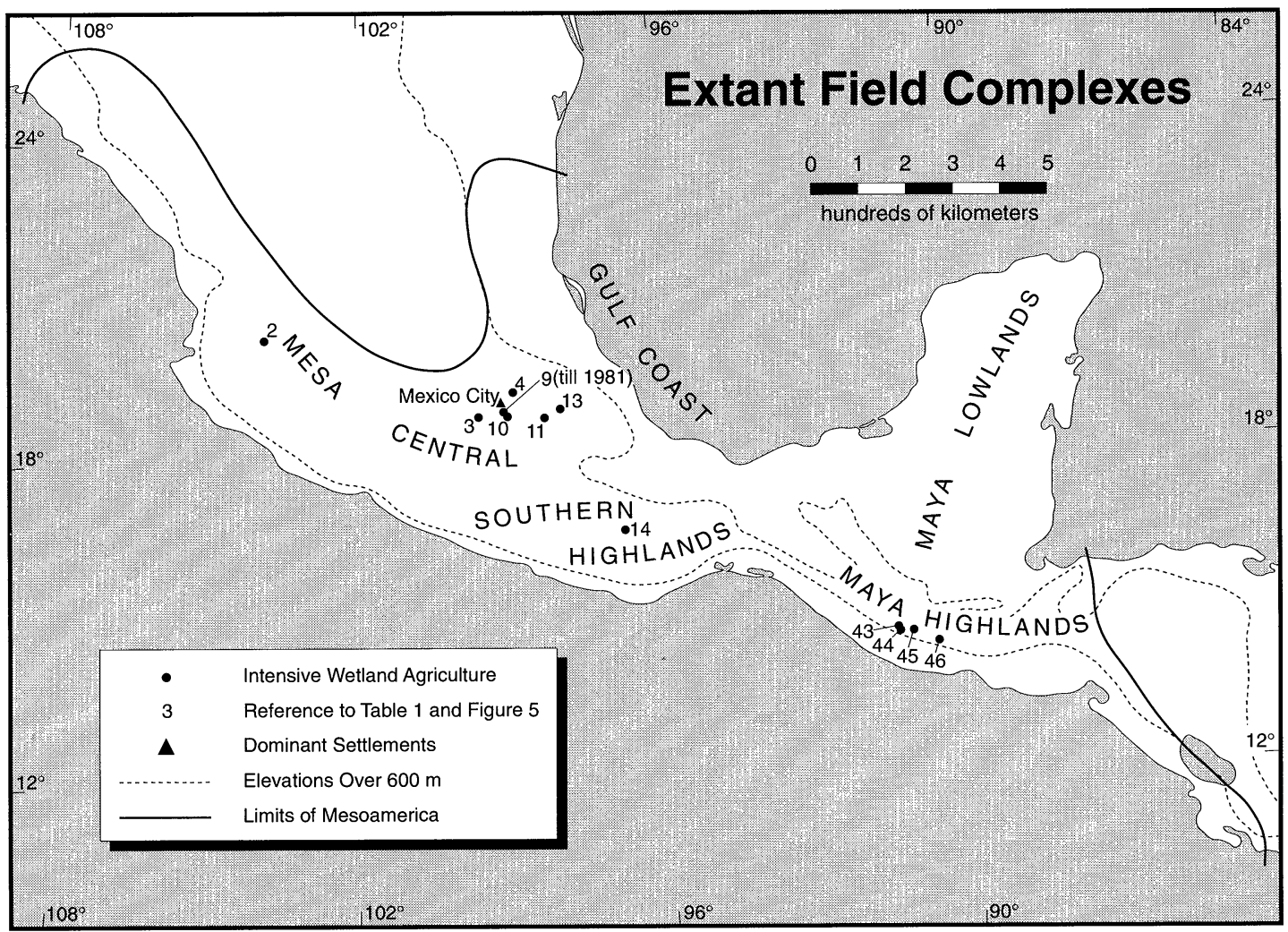

Figure 10. Locations of extant intensive wetland agriculture and dominant settlements. Sources: Table 1. For base map see Porter Weaver 1981: Map 1.

have supported are relatively small. Based on maize yield and consumption for extant chinampas in the Basin of Mexico (Sanders et al. 1979:373, 380, 390), wetland fields might have supported as many as 19 persons/ha/year under single cropping where winter frosts obtain and 28 under double cropping (Denevan 1982:Table 1; Turner and Harrison 1983:Table 13.2). Even accepting these liberal estimates and assuming contemporaneity, the 9,100 confirmed hectares on the flanks of the Maya Lowlands could have fed no more than 255,000 persons per year. Meanwhile, the Classic-period settlement pattern was centered on the core of the peninsula: populations there increased from some 350,000 in A.D. 300 to about 1,500,000 in A.D. 800 (Turner 1990:Table 15.3) and achieved densities as high as 1000 persons $/ \mathrm{km}^{2}$ at the dominant settlements in the Petén such as Tikal (Santley et al. 1986:Ta- ble 1 ). The only evidence thus far for fields in the core is for just 15 ha at Río Azul (Figure 12); and these fields, along with the small hectareages at Cerros (ca. 1.5 ha) and Edzná (ca. 375 ha), ceased production during the Early Classic period, precisely when population densities in the Maya Lowlands increased most rapidly. Conversely, outside of the peninsula's core, the larger hectareages at the northern Belize complexes, Río Candelaria, and Bajo Morocoy probably persisted throughout much of the Classic period (Figure 5).

The small sustaining capacity relative to population and the apparent absence of intensive wetland agriculture at the core of Classicperiod Mayan settlement implies that the importance attributed to wetland fields vis-à-vis the emergence of Maya urbanism (Adams 1980; Turner 1978c; Turner and Harrison 1978; 1979; Mathewson 1977) remains speculative 


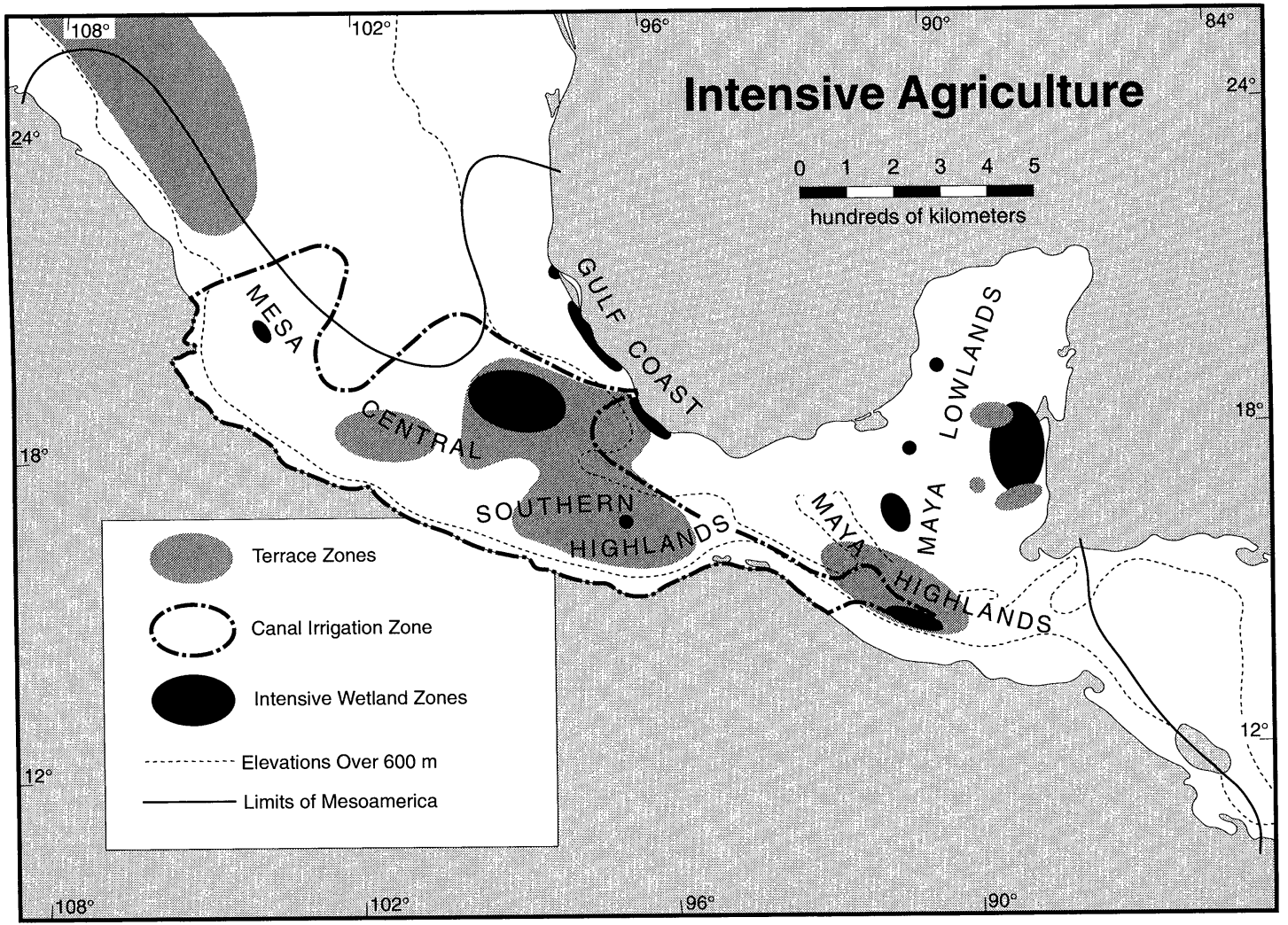

Figure 11. Distributions of terrace, canal irrigation, and intensive wetland agriculture zones. Sources: Table 1; Denevan 1992; Donkin 1979; Doolittle 1990; Mathewson 1984; Palerm 1961; Santley et al. 1986; Sluyter and Siemens 1992; Turner 1978b; Wilken 1987; Base map: Porter Weaver 1981: Map 1.

(Dahlin 1979; 1985; Dahlin et al. 1980; Fedick and Ford 1990; Pope and Dahlin 1989; Sanders 1979). That shifting agriculture alone could not have supported such large urban populations as, for example, the 50,000 estimated for Classic-period Tikal (Turner 1990:Table 15.2) suggests four possibilities: 1) current understanding of Maya population geography is relatively immature (Culbert and Rice 1990), and the main population growth and impetus for Classic-period florescence occurred toward the eastern flank of the peninsula (Turner 1994); 2) wetland fields might have existed in the bajos surrounding Tikal and other settlements, but the vestiges of these fields have been obscured by post-abandonment aggradation (Scarborough and Gallopin 1991); 3) significant long-distance staple transport from fields on the flanks of the peninsula to core settlements might have occurred (Sluyter 1993); and 4) other subsistence strategies supported the dominant settlements (Wilken 1971), e.g., systemic management of microand mesoscale environmental variation in the form of agroforestry (Atran 1993; Sluyter and Siemens 1992).

In contrast, the propinquity of wetland agriculture and dense population is certain in the Basin of Mexico. The Aztec capital of Tenochtitlán had a population of some 300,000 , just one of several large cities in the Basin of Mexico (Sanders 1976b:Table 4.9). The 9,000 ha of wetland fields at Xochimilco-Chalco could have fed some 171,000 persons per year. Despite Palerm's (1973) and Calnek's (1972) seminal research, the extent of the fields surround- 


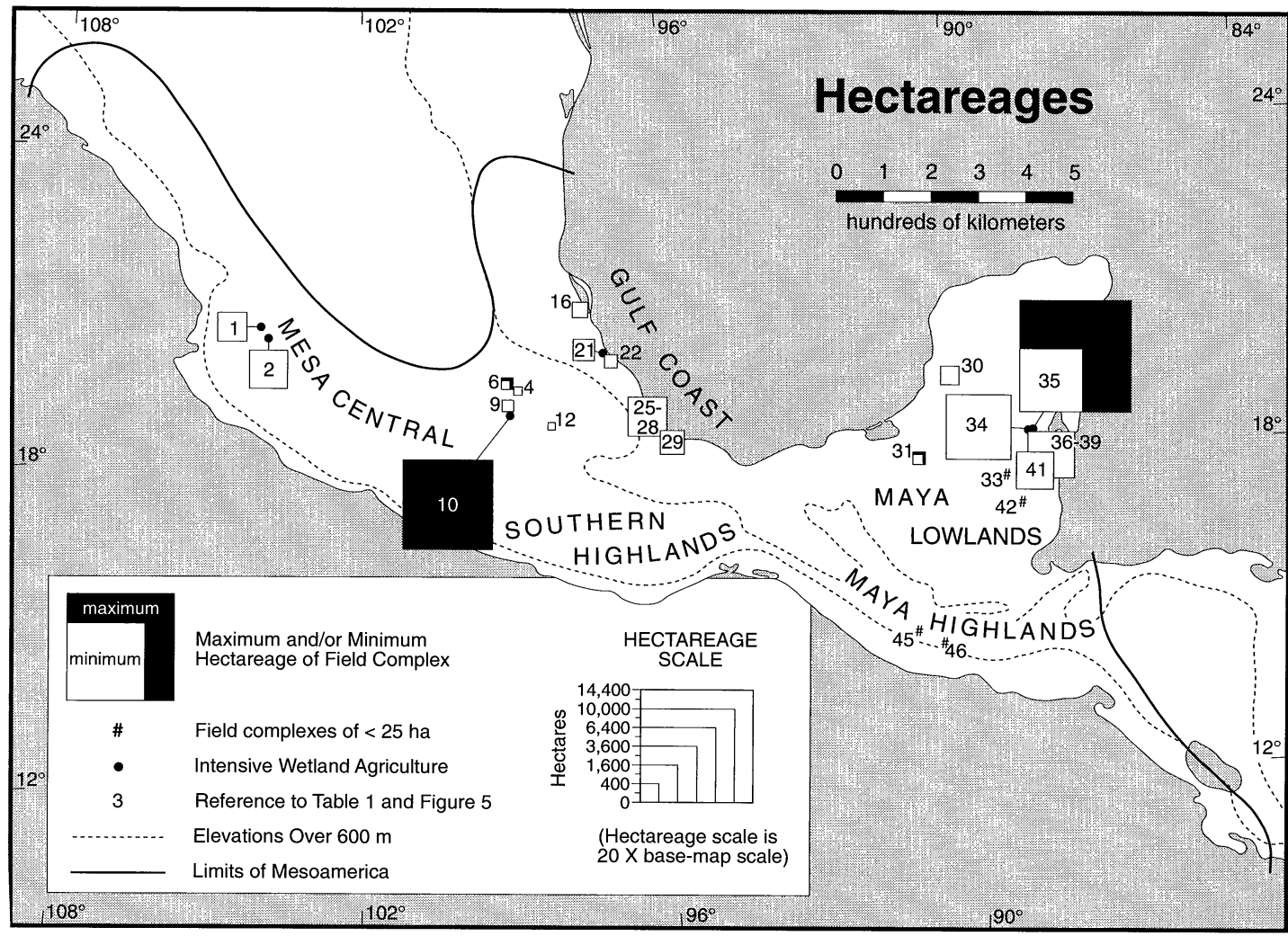

Figure 12. Hectareages of intensive wetland agriculture for all periods for locations with relevant data. Hectareage shown is for field surfaces only, about 75 percent of the total area of the fields and canals. Sources: Table 1. Base map: Porter Weaver 1981: Map 1.

ing Tenochtitlán remains an estimate based on basin hydrology. They certainly were of an equal order of magnitude as the XochimilcoChalco fields. Clearly, the chinampas fed a large proportion of the Basin's inhabitants. Yet, the Aztecs created a vast tribute domain based on their sustained ability, ultimately, to produce agricultural surpluses. A fuller understanding of how will require many more data on wetland field distribution and hectareage.

\section{Morphometry}

Understanding of morphometric variation (Figures 13 and 14) remains quite provisional given the frequent necessity of relying on published photographs and diagrams rather than explicit statements. Nonetheless, four tentative spatial-temporal associations emerge.

The first of these is that field length, width, and amplitude tend to increase through time, most clearly seen in the Mesa Central subregion, but evident panregionally. For example, the width of Iztapalapa fields extant till 1981 exceeds the width of vestigial fields in a ratio of 4 to 1 . Similarly, the Mesa Central fields having tenures through the Postclassic and Historic periods tend to be larger than Maya Lowland fields which persisted only to the Early Postclassic. The evidence is not definitive, however. The small size of fields at Tenochtitlán during the Postclassic period may indicate that large fields did not emerge until the Historic period; hence, the putative trend may be an artifact of still imprecise chronologies. 
Second, fields with linear-curvilinear, biaxial patterns are confined to the Gulf Coast, and, more specifically, to backswamp contexts. Siemens (1983a) has proposed a model that may account for this correlation. He argues that this morphology enabled farmers to regulate drainage at the end of the wet season in such a way that they could plant as early as possible and still retain sufficient water for splash and subirrigation later in the dry season. In the absence of large dams, such a strategy required a labyrinthine canal system punctuated by small dams. The resulting curvilinear morphology contrasts sharply with the linear, uni- and biaxial forms of the Mesa Central lake basins, where subirrigation in conjunction with large dams for controlling water levels and salinities was more critical than drainage (Palerm 1973).

Third, the distinctive morphology of amorphous, radial fields at Edzná in the Maya Lowlands is unique, probably due to their local geological context. Edzná sits in a polje, and the canals may be modified grikes: limestone joints which are widened by solution and sometimes display a radial plan (K. W. Butzer and W. E. Doolittle 1991, personal communication based on a 1987 reconnaissance of Edzná).

Fourth, amorphous shape and irregular pattern only occur in the Maya Lowlands. This association may reflect that the tenure of these fields ended during the Classic and Early Postclassic periods. Elsewhere, as for example in the Mesa Central, field reworking during the Postclassic and Historic periods may have obliterated earlier amorphous fields. Alternatively, this shape and pattern may relate to bajo hydrology rather than technological elaboration.

These patterns suggest more specific and therefore more speculative relationships between morphometry and environment, function, crops, economy, and culture. Flat-profile fields, for example, might have facilitated splash irrigation by minimizing runoff and maximizing infiltration. Cambered-profile fields, in contrast, would have facilitated runoff and drainage, although they are not apparent in the record, possibly due to post-abandonment erosion and sedimentation. Also, a tension would have existed between spatial and subirrigation efficiency. Low frequency systems with wide fields and narrow canals would have poor irrigation characteristics but premium planting-surface-to-canal ratios-possibly an association with surplus production, high population density, or humid climate.

Certainly the environmental context of extant and vestigial fields varies greatly: from hot climates with no dry season to semiarid climates with cool summers; from streams to basins to springs; and from elevations of $2,500 \mathrm{~m}$ to near sea level. But the precise nature of these environments during Prehispanic times remains uncertain. Only the coarsest changes in late-Holocene climate, vegetation, and hydrology are as yet apparent. The evidence from glacial (White 1981; 1986; Heine 1984a; 1984b), lake-level (Bradbury 1971; 1989; Limbrey 1976; Watts and Bradbury 1982; StreetPerrott et al. 1985; Flores Díaz 1986), and pollen records (Graham 1973; Dahlin 1983; Brown 1985; Vaughan et al. 1985) does not correlate particularly well. Nonetheless, these records do provide a general regional climatic sequence: a warmër, drier period than present during the middle Holocene; a cooler, wetter period ca. 1500 B.C. to A.D. 1; a general drying trend since A.D. 1; and interruptions of that trend by cooler, wetter periods ca. A.D. 5001000 and ca. 1400-1850 (Figure 5). Apparently then, agricultural intensification-including that in wetlands-began during the onset of a cooler, wetter climate ca. 1500 B.C. This conjunction may reflect greater reliance on agriculture during a period of climatic and cultural dynamism, although these linkages remain unclear. The ensuing expansion of wetland agriculture during the Late Preclassic-Early Classic transition correlates with the onset of a drier climate, ca. 250 B.C. to A.D. 250. Agricultural expansion at this time occurred in the Mesa Central and the Maya Lowlands, with diffusion to the Gulf Coast. Drier climates might have resulted in greater reliance on wetlands which would have offered both crop security in the face of increasingly uncertain precipitation regimes and increased yields. Initial success in securing crop security furthermore might have stimulated urbanization and population increase in the Classic period on the basis of higher yield.

If a sophisticated understanding of the constructions and functions of wetland fields continues to be elusive, two main interpretations have emerged in the Maya Lowlands. Some researchers favor explanations of construction that are based on field raising through the importation of sediments to raise planting plat- 


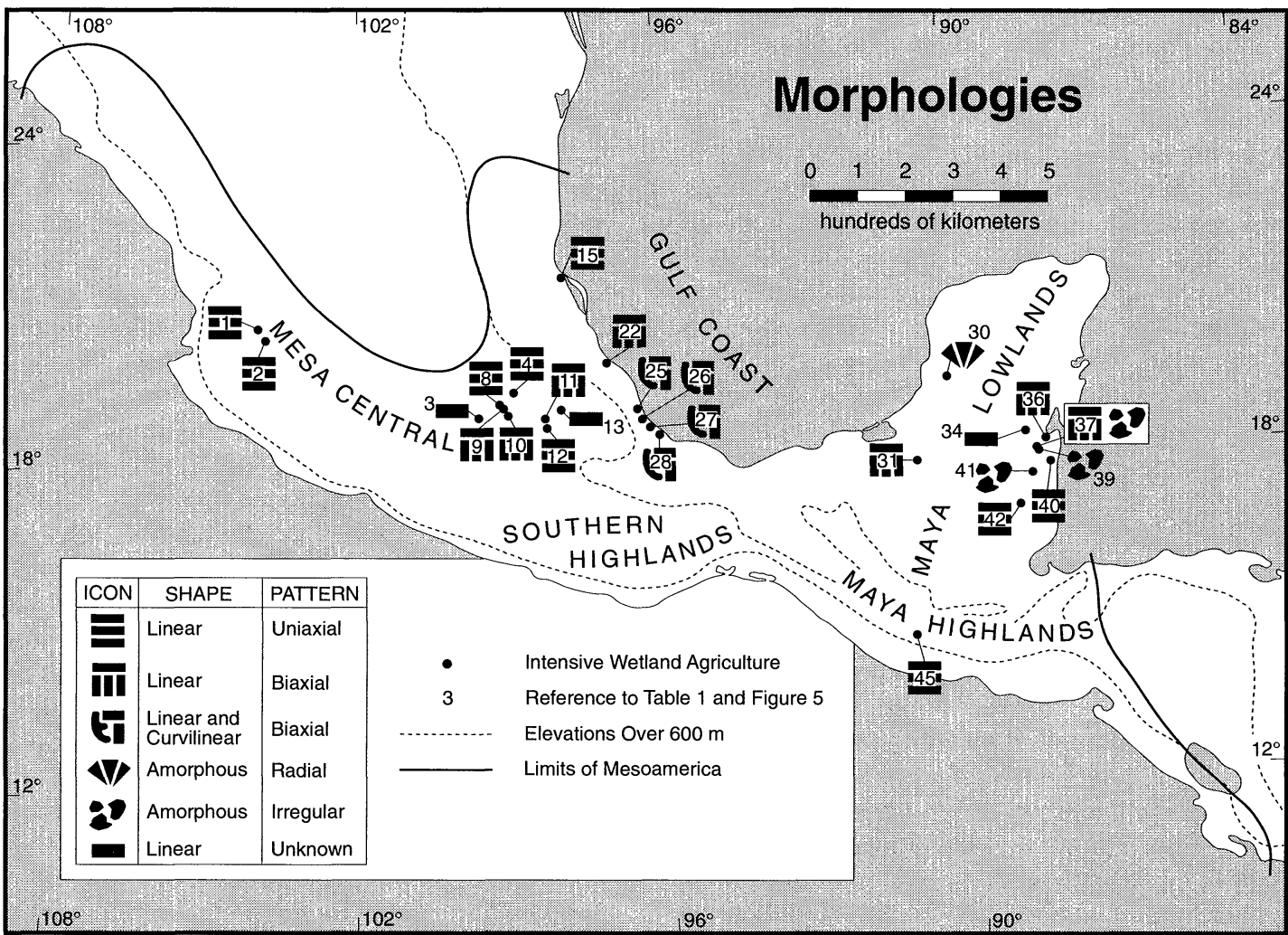

Figure 13. Morphologies of intensive wetland agriculture for all periods for locations with relevant data. Sources: Table 1; Figure 4; Base map: Porter Weaver 1981: Map 1.

forms between canals in bajo contexts (Puleston 1977b; Turner 1983b; 1991), implying a subirrigation function similar to the chinampas of the Basin of Mexico. Other researchers favor channelization with little or no field raising (Pohl et al. 1990), implying a drainage function similar to flood-recessional agriculture. Critiques of the first interpretation note that the origin of calcareous mottles evident in field profiles at Pulltrouser Swamp is natural and therefore not evidence of field raising (Pohl et al. 1990:226). While such criticism has led to revision of the "field-raising hypothesis" (Turner 1993a; 1993b), the discovery of a biface pick within the mottled stratum does indicate human disturbance and the possibility of some field raising, perhaps using canal spoil rather than imported sediments (Turner and Harrison 1983:41-42, 47; Turner 1991). Reconciliation of these opposing interpretations will hinge on new data and likely-given the morphometric variety thus far evident-will reveal that construction and function differed with environmental, economic, and cultural context.

An alternative approach to investigating construction and function has been the experimental one. The construction of fields for food production (Gómez-Pompa et al. 1982) and for understanding Prehispanic practices (Puleston $1977 a ; 1977 b$ ) has yielded limited data thus far. Relying on historical descriptions of chinampa construction in the Basin of Mexico (West and Armillas 1950), experimenters have constructed raised planting platforms out of sediment and vegetation. These field experiments have yielded information on construction inputs and crop productivity. In addition, controlled experiments have focused on specific aspects of function, such as nitrogen and 


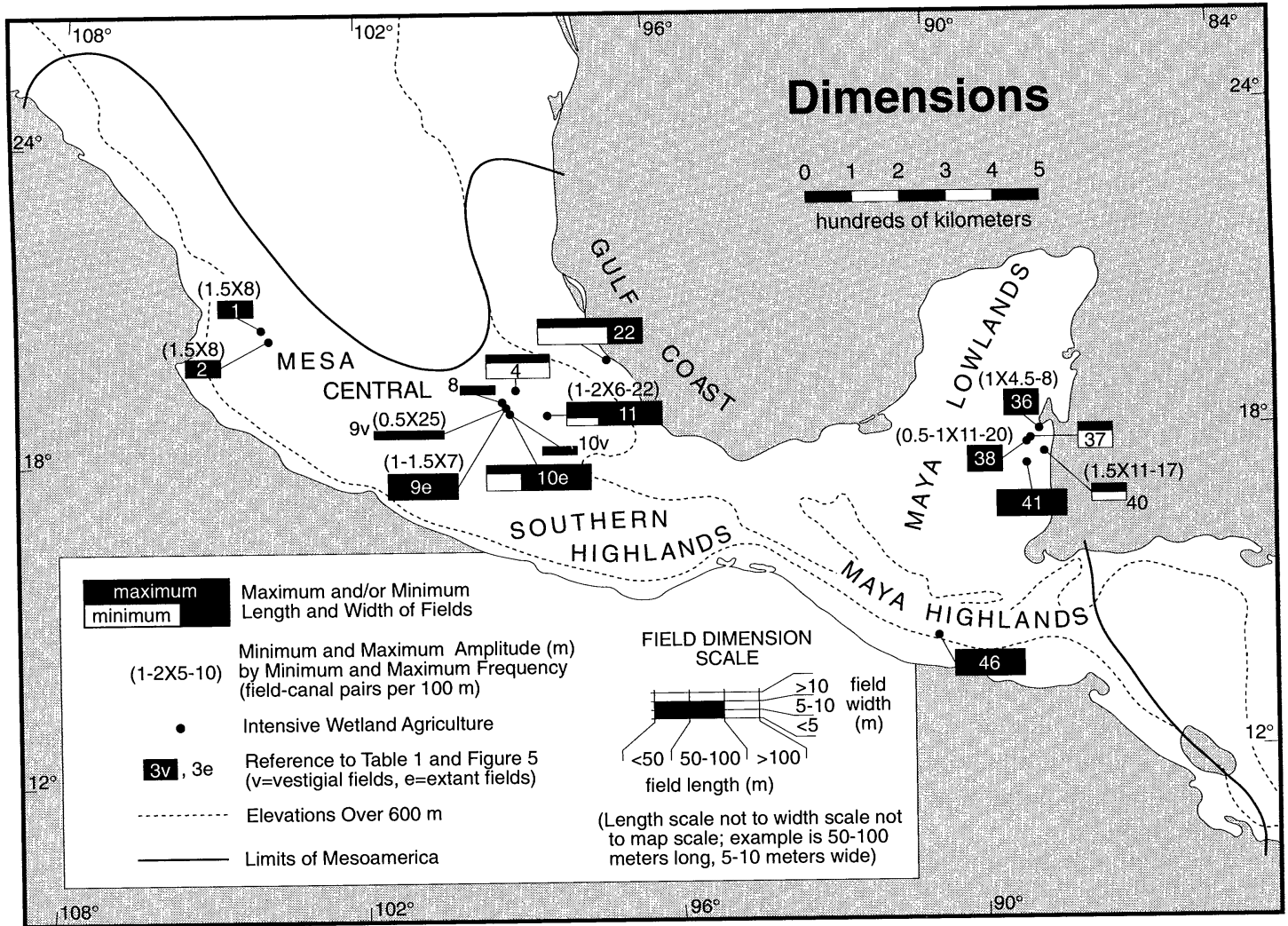

Figure 14. Dimensions of intensive wetland agriculture for all periods for locations with relevant data. Sources: Table 1; Base map: Porter Weaver 1981: Map 1.

phosphorous cycling. The experimental evidence supports the hypothesis that the periodic transfer of bottom sediments from canals to field surfaces, or "mucking," was an integral element of intensive wetland agriculture (Vasey 1983; Vasey et al. 1984). In addition, planting surfaces subject to annual flooding would receive nutrient inputs through sedimentation as well as pest and weed control through submergence (Thurston 1990).

The crops grown on Prehispanic wetland fields remain largely unknown. Direct evidence from excavations is scanty. Sixteenth-century ethnohistorical materials for the Basin of Mexico provide some insights for the last centuries of the Prehispanic period. Maize (Zea mays), squash (Curcurbita spp.), beans (Phaseolus vulgaris), amaranth (Amaranthus spp.), sage or chía (Salvia hispanica), chile (Capsicum an- nuum), tomato (Lycopersicon esculentum) and green tomato (Physalis ixocarpa) were the major crops (Rojas Rabiela 1983b; 1991; Torres 1985). But little is known about crops grown during earlier time periods. In the lowlands, although plant micro- and macrofossils from field excavations confirm only maize (Turner and Miksicek 1984), a series of hypotheses focus on cacao (Theobroma cacao), amaranth (Amaranthus spp.), cotton (Gossypium hirsutum), squash (Cucurbita moschata, C. pepo), and beans (Phaseolus spp.).

\section{The Tasks Ahead}

On the one hand, the database has grown large enough to demand a systematic analysis. On the other hand, the lacuna reflect the lack 
of a coherent research strategy and prevent a more sophisticated analysis and synthesis. Idiosyncratic research priorities and strategies have resulted in data of uneven quality with respect to field chronology, hectareage, and morphometry. Yet, while these data are an insufficient basis for an authoritative synthesis, they do permit provisional identification of significant variables, spatial and temporal trends, and a series of testable hypotheses that may lend coherence to further research. Four such hypotheses address the themes of the introduction:

(1) The emergence and broad distribution of wetland agriculture during the Preclassic period suggests that farmers built wetland fields wherever and whenever social processes elicited dense population nucleations and hydrology was appropriate. Testing this hypothesis will require more sophisticated and persistent prospecting, particularly in the backswamps of the Olmec realm and the bajos in the core of the Maya Lowlands.

(2) The propinquities of intensive wetland agriculture and terracing, canal irrigation, and extensive agroecosystems in time and space suggest that their emergence was ecologically interrelated. Testing will require detailed studies of cases in which these agroecosystems are juxtaposed and in which chronometric controls permit analysis of the interrelationships among crops, environments, and anthropic environmental impacts.

(3) The morphometric variety of wetland fields reflects the environmental and social contexts of landforms, hydrology, population density, levels of taxation and tribute, and the centralization of decision making. Evaluating the relative importance of these contexts will require comparable morphometric data from a large sample of field complexes in the various subregions of Mesoamerica.

(4) The long tenure of wetland agriculture in some locations implies a productive and sustainable agroecosystem that holds promise for transforming social and ecological relations (cf., Browder 1989; Kropotkin 1919; Parsons 1985). Testing will require a refined chronology of the venerable Xochimilco-Chalco fields in order to establish origins, continuities, and transformations in relation to dynamic environmental and social contexts.

\section{Acknowledgments}

Michael D. Myers, William E. Doolittle, William M. Denevan, and two anonymous reviewers made valuable comments on the original draft, many of which I have gratefully incorporated. B. L. Turner II was particularly generous with his time and insights. Social Sciences and Humanities Research Council of Canada and National Aeronautics and Space Administration funding freed research and writing time.

\section{Notes}

1. A more detailed, monographic version of this paper, intended to complement Donkin (1979) on terracing and Doolittle (1990) on canal irrigation, is in preparation.

2. Three forthcoming publications (Adams n.d.; Rice n.d.; Turner n.d.) should provide significant new data and interpretations.

\section{References}

Abascal, R., and García Cook, A. 1975. Sistemas de cultivo, riego y control de agua en el área de Tlaxcala. In XIII mesa redonda, Vol. 1, pp. 199212. México: Sociedad Mexicana de Antropología.

Abascal, R., Dávila, P., Schmidt, P., and Z. de Dávila, D. 1976. Comunicaciones del Proyecto PueblaTlaxcala 2 (supplement):1-74.

Adams, R. E. W. 1980. Swamps, Canals, and the Locations of Ancient Maya Cities. Antiquity 54:206-214.

. 1982. Ancient Maya Canals: Grids and Latices in the Maya Jungle. Archaeology 35(6):2835.

1983. Ancient Land Use and Culture History in the Pasión River Region. In Prehistoric Settlement Patterns: Essays in Honor of Gordon R. Willey, ed. E. Z. Vogt and R. M. Leventhal, pp. 319-335. Cambridge: Harvard University, Peabody Museum of Archaeology and Ethnology and University of New Mexico Press.

_- ed. 1984. Río Azul Project Reports. Number 1, Final 1983 Report. San Antonio: University of Texas at San Antonio, Center for Archaeological Research.

1990. Archaeological Research at the Lowland Maya City of Río Azul. Latin American Antiquity 1:23-41.

1991. Nucleation of Population and Water 
Storage Among the Ancient Maya. Science 251:632.

. 1993. Rebuttal to Pope and Dahlin: 2. Journal of Field Archaeology 20:383.

_ - n.d. The Ancient Maya City of Río Azul. Norman: University of Oklahoma Press. Forthcoming.

Adams, R. E. W., Brown, W. E., Jr., and Culbert, P. T. 1981. Radar Mapping, Archaeology, and Ancient Maya Land Use. Science 213:14571463.

Adams, R. E. W., Culbert, T. P., Brown, W. E., Jr., Harrison, P. D., and Levi, L. J. 1990. Rebuttal to Pope and Dahlin. Journal of Field Archaeology 17:241-244.

Antoine, P. P., Skarie, R. L., and Bloom, P. R. 1982. The Origin of Raised Fields Near San Antonio, Belize: An Alternative Hypothesis. In Maya Subsistence: Studies in Memory of Dennis E. Puleston, ed. K. V. Flannery, pp. 227-236. New York: Academic Press.

Apenes, O. 1943. The "Tlateles" of Lake Texcoco. American Antiquity 9:29-32.

Armillas, P. 1971. Gardens on Swamps. Science 174:653-661.

. 1987. El paisaje agrario Azteca. In La aventura intelectual de Pedro Armillas, ed. J. L. de Rojas, pp. 67-107. Zamora, Michoacán: El Colegio de Michoacán.

Atran, S. 1993. Itza Maya Tropical Agro-forestry. Current Anthropology 34:633-700.

Avila López, R. 1991. Chinampas de Iztapalapa, D.F. México: Instituto Nacional de Antropología e Historia.

Black, S. L. 1987. Settlement Pattern Survey and Testing, 1985. In Río Azul Reports. Number 3, The 1985 Season, ed. R. E. W. Adams, pp. 183221. San Antonio: University of Texas at San Antonio, Center for Archaeological Research.

Black, S. L., and Suhler, C. K. 1986. The 1984 Río Azul Settlement Survey. In Río Azul Reports. Number 2, The 1984 Season, ed. R. E. W. Adams, pp. 163-192. San Antonio: University of Texas at San Antonio, Center for Archaeological Research.

Blanton, R. E., Kowalewski, S. A., Feinman, G., and Appel, J. 1981. Ancient Mesoamerica: A Comparison of Change in Three Regions. Cambridge: Cambridge University Press.

Bloom, P. R., Pohl, M. D., Buttleman, C., Wiseman, F., Covich, A., Miksicek, C., Ball, J., and Stein, J. 1983. Prehistoric Maya Wetland Agriculture and the Alluvial Soils near San Antonio, Río Hondo, Belize. Nature 301:417-419.

Bloom, P. R., Pohl, M. D., and Stein, J. 1985. Analysis of Sedimentation and Agriculture along the Río Hondo, Northern Belize. In Prehistoric Lowland Maya Environment and Subsistence Economy, ed. M. D. Pohl, pp. 21-31. Cambridge: Harvard
University, Peabody Museum of Archaeology and Ethnology.

Bradbury, J. P. 1971. Paleolimnology of Lake Texcoco, Mexico: Evidence from Diatoms. Limnology and Oceanography 16:180-200.

- 1989. Late Quaternary Lacustrine Paleoenvironments in the Cuenca de Mexico. Quaternary Science Reviews 8:75-100.

Browder, J. O., ed. 1989. Fragile Lands of Latin America: Strategies for Sustainable Development. Boulder: Westview.

Brown, R. B. 1985. A Summary of Late-Quaternary Pollen Records from Mexico West of the Isthmus of Tehuantepec. In Pollen Records of Late-Quaternary North American Sediments, ed. V. M. Bryant and R. G. Holloway, pp. 71-93. Dallas: The American Association of Stratigraphic Palynologists Foundation.

Brumfiel, E. M., and Frederick, C. D. 1992. Xaltocan: Centro regional de la Cuenca de México. In Consejo de arqueología, boletín, 1991, pp. 2430. México: Instituto Nacional de Antropología e Historia.

Butzer, K. W., and Doolittle, W. E. 1991. Personal communication.

Calnek, E. E. 1972. Settlement Pattern and Chinampa Agriculture at Tenochtitlan. American Antiquity 37:104-114.

_- 1973. The Localization of the Sixteenth-Century Map Called the Maguey Plan. American Antiquity 38:190-195.

. 1976. The Internal Structure of Tenochtitlán.

In The Valley of Mexico: Studies in Pre-Hispanic Ecology and Society, ed. E. R. Wolf, pp. 287302. Albuquerque: University of New Mexico Press.

1978. The Internal Structure of Cities in America: Pre-Columbian Cities, the Case of Tenochtitlán. In Urbanization in the Americas from its Beginnings to the Present, ed. R. P. Schaedel, J. E. Hardoy, and N. S. Kinzer, pp. 315-326. The Hague: Mouton Publishers.

Chapin, M. 1988. The Seduction of Models: Chinampa Agriculture in Mexico. Grassroots Development 12:8-17.

Coe, M. D. 1964. The Chinampas of Mexico. Scientific American 211:90-98.

Coe, M. D., and Diehl, R. A. 1980. In the Land of the Olmec. Vol. 2, The People of the River. Austin: University of Texas Press.

Crane, C. J. 1986. Late Preclassic Maya Agriculture, Wild Plant Utilization, and Land-Use Practices. In Archaeology at Cerros, Belize, Central America. Vol. 1, An Interim Report, ed. R. A. Robertson and D. A. Freidel, pp. 147-151. Dallas: Southern Methodist University Press.

Culbert, T. P., and Rice, D. S., eds. 1990. Precolumbian Population History in the Maya Lowlands. Albuquerque: University of New Mexico Press. 
Culbert, T. P., Levi, L. J., and Cruz, L. 1990. Lowland Maya Wetland Agriculture: The Río Azul Agronomy Program. In Vision and Revision in Maya Studies, ed. F. S. Clancy and P. D. Harrison, pp. 115-124. Albuquerque: University of New Mexico Press.

Dahlin, B. H. 1979. Preliminary Investigations of Agronomic Potentials in "Bajos" Adjacent to Tikal. Actes du XLlle Congrès International des Américanistes, Paris, 2-9 September 1976 8:305-312.

1983. Climate and Prehistory on the Yucatan Peninsula. Climatic Change 5:245-263.

—. 1985. La geografía histórica de la antigua agricultura Maya. In Historia de la agricultura, época prehispanica-siglo XVI, ed. T. Rojas Rabiela and W. T. Sanders, pp. 125-96. México: Instituto Nacional de Antropología e Historia.

Dahlin, B. H., Foss, J. E., and Chambers, M. E. 1980. Project Acalaches: Reconstructing the Natural and Cultural History of a Seasonal Swamp at EI Mirador, Guatemala, Preliminary Results. In EI Mirador, Petén, Guatemala: An Interim Report, ed. R. T. Matheny, pp. 37-57. Papers of the New World Archaeological Foundation, no. 45. Provo: New World Archaeological Foundation.

Denevan, W. M. 1970. Aboriginal Drained-Field Agriculture in the Americas. Science 169:647-654. 1980a. Investigaciones recientes sobre agricultura precolombina de campos elevados en América Latina. Biótica 5:63-67.

. 1980b. Tipología de configuraciones agrícolas Prehispanicas. América Indígena 40:619-652. 1982. Hydraulic Agriculture in the American Tropics: Forms, Measures, and Recent Research. In Maya Subsistence: Studies in Memory of Dennis E. Puleston, ed. K. V. Flannery, pp. 181-203. New York: Academic Press.

- 1992. The Pristine Myth: The Landscape of the Americas in 1492. Annals of the Association of American Geographers 82:369-385.

Denevan, W. M., and Turner, B. L., II. 1974. Forms, Functions and Associations of Raised Fields in the Old World Tropics. Journal of Tropical Geography 39:24-33.

Donkin, R. A. 1979. Agricultural Terracing in the Aboriginal New World. Tucson: University of Arizona Press.

Doolittle, W. E. 1990. Canal Irrigation in Prehistoric Mexico: The Sequence of Technological Change. Austin: University of Texas Press.

Dunning, N. P. n.d. A Reexamination of Regional Variability in the Prehispanic Agricultural Landscape. Forthcoming in Ancient Maya Subsistence Resource Management, ed. S. L. Fedick. Provo: University of Utah Press.

Dunning, N. P., Rue, D., and Beach, T. 1991. Ecología y patrón de asentamiento en la región de Petexbatún: Resultados preliminares de la temporada 1991. In Proyecto arqueológico regional Petexbatún. Informe preliminar \#3, Tercera temporada 1991, ed. A. A. Demarest, pp. 829-847. Nashville: Vanderbilt University.

Fedick, S. L., and Ford, A. 1990. The Prehistoric Agricultural Landscape of the Central Maya Lowlands: An Examination of Local Variability in a Regional Context. World Archaeology 22:13-33.

Flores-Díaz, A. 1986. Fluctuaciones de Lago de Chalco desde hace 35 Mil años al presente. In Tlapacoya: 35,000 años de historia de Lago de Chalco, ed. J. L. Lorenzo and L. Mirambell, pp. 109-156. México: Instituto Nacional de Antropología e Historia.

Fowler, M. L. 1969. A Preclassic Water Distribution System in Amalucan, Mexico. Archaeology 22:208-215.

. 1978. The Temple Town Community: Cahokia and Amalucan Compared. In Urbanization in the Americas from its Beginnings to the Present, ed. R. P. Schaedel, J. E. Hardoy, and N. S. Kinzer, pp. 175-184. The Hague: Mouton Publishers.

1987. Early Water Management at Amalucan, State of Puebla, Mexico. National Geographic Research 3:52-68.

Freidel, D. A., and Scarborough, V. 1982. Subsistence, Trade, and Development of the Coastal Maya. In Maya Subsistence: Studies in Memory of Dennis E. Puleston, ed. K. V. Flannery, 131155. New York: Academic Press.

García Cook, A. 1974. Una secuencia cultural para Tlaxcala. Comunicaciones del Proyecto PueblaTlaxcala 10:5-22.

. 1981. The Historical Importance of Tlaxcala in the Cultural Development of the Central Highlands. In Supplement to the Handbook of Middle American Indians. Vol. 1, Archaeology, ed. J. A. Sabloff, pp. 224-276. Austin: University of Texas Press.

1985. Historia de la tecnología agrícola en el altiplano central desde el principio de la agricultura hasta el siglo XIII. In Historia de la agricultura, época prehispanica-siglo XVI, Vol. 2, ed. T. Rojas Rabiela and W. T. Sanders, pp. 7-75. México: Instituto Nacional de Antropología e Historia.

- 1986. El control de la erosión en Tlaxcala: Un problema secular. Erdkunde 40:251-262.

García Cook, A., and Merino Carrión, B. L. 1990. El cultivo intensivo: Condiciones sociales y ambientales que lo originan. In Agricultura indígena: Pasado y presente, ed. T. Rojas Rabiela, pp. 6987. México: Centro de Investigaciones y Estudios Superiores en Antropología Social.

García Mora, C. 1979. Nota para la antropología de la subcuenca Chalca de Valle de México. Biótica 4:13-32.

Gliessman, S. R., Turner, B. L., II, Rosado May, F. J., 
and Amador, M. F. 1983. Ancient Raised Field Agriculture in the Maya Lowlands of Southeastern Mexico. In Drained Field Agriculture in Central and South America, ed. J. P. Darch, pp. 91-110. Oxford: British Archaeological Reports.

- $\longrightarrow$, and - 1985. Ancient

Raised Field Agriculture in the Maya Lowlands of Southeastern Mexico. In Prehistoric Intensive Agriculture in the Tropics, ed. I. S. Farrington, pp. 97-111. Oxford: British Archaeological Reports.

Gómez-Pompa, A. 1978. An Old Answer to the Future. Mazingira 5:50-55.

Gómez-Pompa, A., Morales, H. L., Jiménez Avilla, E., and Jiménez Avilla, J. 1982. Experiences in Traditional Hydraulic Agriculture. In Maya Subsistence: Studies in Memory of Dennis E. Puleston, ed. K. V. Flannery, pp. 327-342. New York: Academic Press.

Graham, A. 1973. Literature on the Vegetational History of Latin America. In Vegetation and Vegetational History of Northern Latin America, ed. A. Graham, pp. 315-360. Amsterdam: Elsevier.

Hammond, N. 1983. Nohmul, Belize: 1982 Investigations. Journal of Field Archaeology 10:245-254.

- 1985. Nohmul: A Prehistoric Maya Community in Belize, Excavations 1973-1983. Oxford: British Archaeological Reports.

- 1990. Ancient Maya Civilization. New Brunswick: Rutgers University Press.

Hammond, N., Clark, C., Horton, M., Hodges, L., McNatt, L., Kosakowsky, L. J., and Pyburn, A. 1985. Excavation and Survey at Nohmul, Belize, 1983. Journal of Field Archaeology 12:177-200.

Hammond, N., Donaghey, S., Gleason, C., Staneko, J. C., Van Tuerenhout, D., and Kosakowsky, L. J. 1987. Excavations at Nohmul, Belize, 1985. Journal of Field Archaeology 14:257-281.

Harrison, P. D. 1977. The Rise of the Bajos and the Fall of the Maya. In Social Process in Maya Prehistory: Studies in Memory of Sir Eric Thompson, ed. N. Hammond, pp. 469-508. London: Academic Press.

. 1978. Bajos Revisited: Visual Evidence for One System of Agriculture. In Pre-Hispanic Maya Agriculture, ed. P. D. Harrison and B. L. Turner, II, pp. 247-253. Albuquerque: University of New Mexico Press.

—. 1982. Subsistence and Society in Eastern Yucatan. In Maya Subsistence: Studies in Memory of Dennis E. Puleston, ed. K. V. Flannery, pp. 119-130. New York: Academic Press.

- 1990. The Revolution in Ancient Maya Subsistence. In Vision and Revision in Maya Studies, ed. F. S. Clancy and P. D. Harrison, pp. 99-113. Albuquerque: University of New Mexico Press.

Hebda, R. J., Siemens, A. H., and Robertson, A. J.
1991. Stratigraphy, Depositional Environment, and Cultural Significance of Holocene Sediments in Patterned Wetlands of Central Veracruz, Mexico. Geoarchaeology 6:61-84.

Heine, K. 1984a. The Classical Late Weichselian Climatic Fluctuations in Mexico. In Climatic Changes on a Yearly to Millennial Basis, ed. N.-A. Morner and W. Karlen, pp. 95-115. Dordrecht, The Netherlands: D. Reidel.

. 1984b. Comment on Pleistocene Glaciation of Volcan Ajusco, Central Mexico, and Comparison with the Standard Mexican Glacial Sequence, by Sidney E. White and Salvatore Valastro, Jr. Quaternary Research 22:242-246.

Humboldt, A. von. 1966. Political Essay on the Kingdom of New Spain. New York: AMS Press.

Jacob, J. S. 1992. The Agroecological Evolution of Cobweb Swamp, Belize. Unpublished Ph.D. dissertation, Texas Agricultural and Mechanical University.

Kirchhoff, P. 1943. Mesoamerica. Acta Americana 1:92-107.

Kirke, C. M. St. G. 1980. Prehistoric Agriculture in the Belize River Valley. World Archaeology 11:281-286.

Kropotkin, P. 1919. Fields, Factories and Workshops: Or, Industry Combined with Agriculture and Brain Work with Manual Work. London: Thomas Nelson and Sons.

Lambert, J. D. H. 1985. The Ecological Consequences of Ancient Maya Agricultural Practices in Belize. In Prehistoric Intensive Agriculture in the Tropics, ed. I. S. Farrington, pp. 113-126. Oxford: British Archaeological Reports.

Lambert, J. D. H., and Arnason, J. T. 1983. Ancient Maya Land Use and Potential Agricultural Productivity at Lamanai, Belize. In Drained Field Agriculture in Central and South America, ed. J. P. Darch, pp. 111-122. Oxford: British Archaeological Reports.

Lambert, J. D. H., Siemens, A. H., and Arnason, J. T. 1984. Ancient Maya Drained Field Agriculture: Its Possible Application Today in the New River Floodplain, Belize, C.A. Agriculture, Ecosystems and Environment 11:67-87.

Limbrey, S. 1976. Tlapacoya: Problems of Interpretation of Lake Margin Sediments at an Early Occupation Site at the Basin of Mexico. In Geoarchaeology, ed. D. A. Davidson and M. L. Shakley, pp. 213-226. London: Duckworth.

López Ríos, G. F. 1988. Chinampas: Perspectiva agroecológica. México: Universidad Autónoma Chapingo.

Matheny, R. T. 1976. Maya Lowland Hydraulic Systems. Science 193:639-646.

. 1978. Northern Maya Lowland Water-Control Systems. In Pre-Hispanic Maya Agriculture, ed. P. D. Harrison and B. L. Turner II, pp. 185- 
210. Albuquerque: University of New Mexico Press.

. 1982. Ancient Lowland and Highland Maya Water and Soil Conservation Strategies. In Maya Subsistence: Studies in Memory of Dennis E. Puleston, ed. K. V. Flannery, pp. 157-178. New York: Academic Press.

Matheny, R. T., and Gurr, D. L. 1983. Variation in Prehistoric Agricultural Systems of the New World. Annual Review of Anthropology 12:79103.

Matheny, R. T., Forsyth, D. W., and Hauck, F. R. 1983. Investigations at Edzna, Campeche, Mexico. Vol. 1, part 1, The Hydraulic System. Papers of the New World Archaeological Foundation, no. 46. Provo: Brigham Young University.

Mathewson, K. 1977. Maya Urban Genesis Reconsidered: Trade and Intensive Agriculture as Primary Factors. Journal of Historical Geography 3:203-215.

- 1984. Irrigation Horticulture in Highland Guatemala: The Tablón System of Panajachel. Boulder: Westview Press.

- 1985. Taxonomy of Raised and Drained Fields: A Morphogenetic Approach. In Prehistoric Intensive Agriculture in the Tropics, ed. I. S. Farrington, pp. 835-864. Oxford: British Archaeological Reports.

McClung de Tapia, E., Serra Puche, M. C., and Limón de Dyer, A. E. 1986. Formative Lacustrine Adaptation: Botanical Remains from Terremote-Tlaltenco, D.F., México. Journal of Field Archaeology 13:99-113.

Millon, R., ed. 1973. The Teotihuacan Map. Austin: University of Texas Press.

Moriarty, J. R. 1968. Floating Gardens (Chinampas) Agriculture in the Old Lakes of Mexico. América Indigena 28:461-484.

Nichols, D. L., and Frederick, C. D. 1993. Irrigation Canals and Chinampas: Recent Research in the Northern Basin of Mexico. In Economic Aspects of Water Management in the Prehispanic New World; Research in Economic Anthropology, supplement 7, ed. B. Isaacs and V. Scarborough, pp. 123-150. London: JAI Press.

Niederberger, C. 1987. Paleopaysages et archaeologie pre-urbaine du Bassin de Mexico (Mexique). México: Centre D'Etudes Mexicaines et Centraamericaines.

Noguera, E. 1943. Excavations en el Tepalcate, Chimalhuacan, Mexico. American Antiquity 9:3343.

Nuttall, Z. 1925. The Gardens of Ancient Mexico. Smithsonian Institution Annual Report for 1923, pp. 453-465. Washington: Smithsonian Institution.

Olson, G. W. 1977. Significance of Physical and Chemical Characteristics of Soils at the San Antonio Archaeological Site on the Río Hondo in
Northern Belize. In The Río Hondo Project: An Investigation of the Maya of Northern Belize, ed. A. H. Siemens, pp. 22-35. Journal of Belizean Affairs 5 .

Olson, G. W., Siemens, A. H., Puleston, D. E., Cal, G., and Jenkins, D. 1975. Ridged Fields in British Honduras. Soil Survey Horizons 16:9-12.

Orozco-Segovia, A. D. L., and Gliessman, S. R. 1979. The Marceño in Flood-prone Regions of Tabasco, Mexico. Paper presented at the XLIII International Congress of Americanists, Vancouver.

Palerm, A. 1955. The Agricultural Basis of Urban Civilization in Mesoamerica. Social Science Monographs 1:28-42.

—. 1961. Distribución del regadío prehispanico en el area central de Mesoamerica. Revista Interamericana de Ciencias Sociales 1:242-266.

- 1973. Obras hidráulicas prehispanicas en el sistema lacustre del Valle de México. México: Instituto Nacional de Antropología e Historia.

Palerm, A., and Wolf, E. R. 1957. Ecological Potential and Cultural Development in Mesoamerica. Social Science Monographs 3:1-37.

Parsons, J. J. 1985. On "Bioregionalism" and "Watershed Consciousness." Professional Geographer $37: 1-6$.

Parsons, J. R. 1976. The Role of Chinampa Agriculture in the Food Supply of Aztec Tenochtitlán. In Cultural Change and Continuity: Essays in Honor of James Bennett Griffin, ed. C. E. Cleland, pp. 233-257. New York: Academic Press.

- 1991. Political Implications of Prehispanic Chinampa Agriculture in the Valley of Mexico. In Land and Politics in the Valley of Mexico, ed. H. R. Harvey, pp. 17-41. Albuquerque: University of New Mexico Press.

Parsons, J. R., Brumfiel, E., Parsons, M. H., and Wilson, D. J. 1982. Prehispanic Settlement Patterns in the Southern Valley of Mexico: The ChalcoXochimilco Region. Memoirs of the Museum of Anthropology, no. 14. Ann Arbor: University of Michigan.

Parsons, J. R., Parsons, M. H., Popper, V., and Taft, M. 1985. Chinampa Agriculture and Aztec Urbanization in the Valley of Mexico. In Prehistoric Intensive Agriculture in the Tropics, ed. I. S. Farrington, pp. 49-96. Oxford: British Archaeological Reports.

Pohl, M. D., ed. 1990. Ancient Maya Wetland Agriculture: Excavations on Albion Island, Northern Belize. Boulder: Westview Press.

Pohl, M. D., Bloom, P. R., and Pope, K. O. 1990. Interpretation of Wetland Farming in Northern Belize: Excavations at San Antonio Río Hondo. In Ancient Maya Wetland Agriculture: Excavations on Albion Island, Northern Belize, ed. M. D. Pohl, pp. 187-254. Boulder: Westview Press.

Pope, K. O., and Dahlin, B. H. 1989. Ancient Maya Wetland Agriculture: New Insights from Ecologi- 
cal and Remote Sensing Research. Journal of Field Archaeology 16:87-106.

—, and - 1993. Radar Detection and Ecology of Ancient Maya Canal Systems-Reply to Adams et al. Journal of Field Archaeology 20:379-383.

Porter Weaver, M. 1981. The Aztecs, Maya, and their Predecessors. San Diego: Academic Press.

Prem, H. J. 1975. Los afluentes del Río Xopanac, estudio histórico de un sistema de riego. Comunicaciones del Proyecto Puebla-Tlaxcala 12:27-39.

Puleston, D. E. 1977a. The Art and Archaeology of Hydraulic Agriculture in the Maya Lowlands. In Social Process in Maya Prehistory: Studies in Honor of Sir Eric Thompson, ed. N. Hammond, pp. 449-467. London: Academic Press.

1977b. Experiments in Prehistoric Raised Field Agriculture: Learning from the Past. In The Río Hondo Project: An Investigation of the Maya of Northern Belize, ed. A. H. Siemens, pp. 3643. Journal of Belizean Affairs 5 .

1978. Terracing, Raised Fields, and Tree Cropping in the Maya Lowlands: A New Perspective on the Geography of Power. In Pre-Hispanic Maya Agriculture, ed. P. D. Harrison and B. L. Turner II, pp. 225-245. Albuquerque: University of New Mexico Press.

. 1979. The Seeds of Statehood: Variability in Subsistence Modes in the Southern Maya Lowlands and the Rise of Maya Subsistence. Actes du XLlle Congrès International des Américanistes, Paris, 2-9 Sept. 1976 8:401-417.

Rice, D. n.d. Eighth-Century Physical Geography, Environment, and Natural Resources in the Maya Lowlands. Forthcoming in New Perspectives on Classic Maya Civilization: Lowland Societies in the Eighth Century A.D., ed. J. Sabloff and J. Henderson. Washington: Dumbarton Oaks.

Rojas Rabiela, T. 1983a. La agricultura chinampera: Compilación histórica. México: Universidad Autónoma de México.

. 1983b. Evolución histórica del repertorio de plantas cultivadas en las chinampas de la cuenca de México. In Drained Field Agriculture in Central and South America, ed. J. P. Darch, pp. 137165. Oxford: British Archaeological Reports.

. 1991. Ecological and Agricultural Changes in the Chinampas of Xochimilco-Chalco. In Land and Politics in the Valley of Mexico, ed. H. R. Harvey, pp. 275-290. Albuquerque: University of New Mexico Press.

Rojas Rabiela, T., Strauss K., R. A., and Lameiras, J. 1974. Nuevas noticias sobre las obras hidraulicas Prehispanicas y coloniales en el Valle de México. México: Instituto Nacional de Antropología e Historia.

Sanders, W. T. 1976a. The Agricultural History of the Basin of Mexico. In The Valley of Mexico: Studies in Pre-Hispanic Ecology and Society, ed. E. R.
Wolf, pp. 101-159. Albuquerque: University of New Mexico Press.

. 1976b. The Population of the Central Mexican Symbiotic Region, the Basin of Mexico, and the Teotihuacan Valley in the Sixteenth Century. In The Native Population of the Americas in 1492, ed. W. M. Denevan, pp. 85-150. Madison: University of Wisconsin Press.

. 1979. The Jolly Green Giant in Tenth Century Yucatan, or Fact and Fancy in Classic Maya Agriculture. Reviews in Anthropology 6:493506.

Sanders, W. T., Kovar, A., Charlton, T., and Diehl, R. A. 1970. The Teotihuacan Valley Project Final Report. Vol. 1. The Natural Environment, Contemporary Occupation, and 16th Century Population of the Valley. Occasional Papers in Anthropology, no. 3. University Park, Pennsylvania: Pennsylvania State University.

Sanders, W. T., Parsons, J. R., and Santley, R. S. 1979. The Basin of Mexico: Ecological Processes in the Evolution of a Civilization. New York: Academic Press.

Sanders, W. T., West, M., Fletcher, C., and Marino, J. 1975. The Teotihuacan Valley Project Final Report. Vol. 2, part 1, The Formative Period Occupation of the Valley, Texts and Tables. Occasional Papers in Anthropology, no. 10. University Park, Pennsylvania: Pennsylvania State University.

Santamaría, M. 1912. Las chinampas del Distrito Federal. México: Secretaría de Fomento.

Santley, R. S., Killion, T. W., and Lycett, M. T. 1986. On the Maya Collapse. Journal of Anthropological Research 42:123-159.

Scarborough, V. L. 1983a. A Preclassic Maya Water System. American Antiquity 48:720-744.

_ 1983b. Raised Field Detections at Cerros, Northern Belize. In Drained Field Agriculture in Central and South America, ed. J. P. Darch, pp. 123-136. Oxford: British Archaeological Reports.

- 1986. Drainage Canal and Raised Field Excavations. In Archaeology at Cerros, Belize, Central America. Vol. 1, An Interim Report, eds. R. A. Robertson and D. A. Freidel, pp. 75-87. Dallas: Southern Methodist University Press.

Scarborough, V. L., and Gallopin, G. G. 1991. A Water Storage Adaptation in the Maya Lowlands. Science 251:658-662.

Schilling, E. 1938. Die 'Schwimmenden Garten' von Xochimilco. Schriften des Geographischen Institutes der Universitat Kiel, Band IX, Heft 3.

Schmidt, P. J. 1977. Un sistema de cultivo intensivo en la cuenca del Río Nautla, Veracruz. Boletín de Instituto de Antropología e Historia 20:5060.

Serra Puche, M. C. 1988. Los recursos lacustres de la cuenca de México durante el Formativo. 
México: Universidad Nacional Autónoma de México.

. 1990. Los recursos lacustres durante el Formativo en la cuenca de México. In Agricultura Indigena: Pasado y presente, ed. T. Rojas Rabiela, pp. 35-42. México: Centro de Investigaciones y Estudios Superiores en Antropología Social.

Siemens, A. H., ed. 1977. The Río Hondo Project: An Investigation of the Maya of Northern Belize. Journal of Belizean Affairs 5.

. 1978. Karst and the Pre-Hispanic Maya in the Southern Lowlands. In Pre-Hispanic Maya Agriculture, ed. P. D. Harrison and B. L. Turner II, pp. 117-143. Albuquerque: University of New Mexico Press.

1979. Pre-Hispanic Use of Wetlands in the Tropical Lowlands of Mesoamerica. Unpublished manuscript in possession of the author.

. 1980. Indicios de aprovechamiento agricola Prehispanico de tierras inundables en el centro de Veracruz. Biótica 5:83-92.

. 1982a. Aprovechamiento agrícola Precolombiano de tierras inundables en el norte de Veracruz. Biótica 7:343-357.

1982b. Prehispanic Agricultural Use of the Wetlands of Northern Belize. In Maya Subsistence: Studies in Memory of Dennis E. Puleston, ed. K. V. Flannery, pp. 205-225. New York: Academic Press.

—. 1983a. Wetland Agriculture in Pre-Hispanic Mesoamerica. Geographical Review 73:166181.

1983b. Oriented Raised Fields in Central Veracruz. American Antiquity 48:85-102.

. 1983c. Modelling Prehispanic Hydroagriculture on Levee Backslopes in Northern Veracruz, Mexico. In Drained Field Agriculture in Central and South America, ed. J. P. Darch, pp. 27-54. Oxford: British Archaeological Reports.

1985. Results of Recent Air Reconnaissance over the Mexican State of Veracruz. In Prehistoric Intensive Agriculture in the Tropics, ed. I. S. Farrington, pp. 127-148. Oxford: British Archaeological Reports.

- 1989. Tierra configurada: Investigaciones de los vestigios de agricultura Precolumbiana en tierras inundables costeras desde el norte de Veracruz hasta Belice. México: Consejo Nacional para la Cultura y las Artes.

1990. Reducing the Risk: Some Indications Regarding Pre-Hispanic Wetland Agricultural Intensification from Contemporary Use of a Wetland/Terra Firma Boundary Zone in Central Veracruz. In Agroecology: Researching the Ecological Basis for Sustainable Agriculture, ed. S. R. Gliessman, pp. 233-250. New York: SpringerVerlag.

1992. A Favored Place: An Interpretation of the Development of a Wetland Landscape in
Central Veracruz, Mexico. In Person, Place and Thing, ed. Shue Tuck Wong, pp. 195-210. Geoscience and Man, Vol. 31. Baton Rouge, Louisiana: Geoscience Publications, Louisiana State University.

Siemens, A. H., and Puleston, D. E. 1972. Ridged Fields and Associated Features in Southern Campeche: New Perspectives on the Lowland Maya. American Antiquity 37:228-239.

Siemens, A. H., Hebda, R. J., Navarrette Hernandez, M., Piperno, D. R., Stein, J. K., and Zola Baez, M. C. 1988. Evidence for a Cultivar and a Chronology from Patterned Wetlands in Central Veracruz, Mexico. Science 242:105-107.

Sluyter, A. 1990. Vestiges of Upland Fields in Central Veracruz: A New Perspective on its Precolumbian Human Ecology. Published M.A. thesis, University of British Columbia. Ottawa: National Library of Canada Microfilms.

1993. Long-Distance Staple Transport in Western Mesoamerica: Insights through Quantitative Modeling. Ancient Mesoamerica 4:193199.

Sluyter, A., and Siemens, A. H. 1992. Vestiges of Prehispanic, Sloping-Field Terraces on the Piedmont of Central Veracruz, Mexico. Latin American Antiquity 3:148-160.

Smith, C. E., and Tolstoy, P. 1981. Vegetation and Man in the Basin of Mexico. Economic Botany 35:415-433.

Stark, B. L. 1977. Prehistoric Ecology at Patarata 52, Veracruz, Mexico: Adaptation to the Mangrove Swamp. Publications in Anthropology, no. 18. Nashville: Vanderbilt University.

- 1990a. The Gulf Coast and the Central Highlands of Mexico: Alternative Models for Interaction. Research in Economic Anthropology 12:243-285.

1990b. Proyecto arqueológico La Mixtequilla. In Consejo de arqueología, boletín, 1989, pp. 134-137. México: Instituto Nacional de Antropología e Historia.

Street-Perrott, F. A., Roberts, N., and Metcalfe, S. 1985. Geomorphic Implications of Late Quaternary Hydrological and Climatic Change in the Northern Hemisphere Tropics. In Environmental Change and Tropical Geomorphology, ed. I. Douglas and T. Spencer, pp. 165-183. London: Allen and Unwin.

Sugiura Yamamoto, Y., and Serra Puche, M. C. 1983. Notas sobre el modo de subsistencia lacustre, la Laguna de Santa Cruz Atizapan, Estado de México. Anales de Antropología, UNAM 20:926.

Thurston, H. D. 1990. Plant Disease Management Practices of Traditional Farmers. Plant Disease 74:96-102.

Tolstoy, P. 1975. Settlement and Population Trends in the Basin of Mexico (Ixtapaluca and Zaca- 
tenco Phases). Journal of Field Archaeology 2:331-349.

Tolstoy, P., Fish, S. K., Boksenbaum, M. W., Vaughn, K. B., and Smith, C. E. 1977. Early Sedentary Communities of the Basin of Mexico. Journal of Field Archaeology 4:91-106.

Torres, B. 1985. Las plantas útiles en el México antiguo según las fuentes del siglo XVI. In Historia de la agricultura, época Prehispanica-siglo XVI, Vol. 1, ed. T. Rojas Rabiela and W. T. Sanders, pp. 53-128. México: Instituto Nacional de Antropología e Historia.

Turner, B. L., II. 1974. Prehistoric Intensive Agriculture in the Mayan Lowlands. Science 185:118124.

. 1978a. Agricultura prehistórica intensiva en las tierras bajas de los Mayas. América Indígena 38:105-124.

. 1978b. Ancient Agricultural Land Use in the Central Maya Lowlands. In Pre-Hispanic Maya Agriculture, ed. P. D. Harrison and B. L. Turner II, pp. 163-183. Albuquerque: University of New Mexico Press.

. 1978c. The Development and Demise of the Swidden Thesis of Maya Agriculture. In Pre-Hispanic Maya Agriculture, ed. P. D. Harrison and B. L. Turner II, pp. 13-22. Albuquerque: University of New Mexico Press.

- 1983a. Comparison of Agrotechnologies in the Basin of Mexico and Central Maya Lowlands: Formative to the Classic Maya Collapse. In Highland-Lowland Interaction in Mesoamerica: Interdisciplinary Approaches, ed. A. G. Miller, pp. 13-47. Washington: Dumbarton Oaks Research Library and Collection.

. 1983b. The Excavations of Raised and Channelized Fields at Pulltrouser Swamp. In Pulltrouser Swamp: Ancient Maya Habitat, Agriculture, and Settlement in Northern Belize, ed. B. L. Turner II and P. D. Harrison, pp. 30-51. Austin: University of Texas Press.

— 1986. Mystery of the Maya Revealed: The Agricultural Base of a Tropical Civilization. Focus 36(2):2-7.

. 1990. Population Reconstruction of the Central Maya Lowlands: 1000 B.C. to A.D. 1500. In Precolumbian Population History in the Maya Lowlands, ed. T. P. Culbert and D. S. Rice, pp. 301-324. Albuquerque: University of New Mexico Press.

. 1991. Review of Ancient Maya Wetland Agriculture: Excavations on Albion Island, Northern Belize, by M. DeLand Pohl, ed. American Antiquity 56:736-737.

. 1993a. Interpreting the Evidence for Intensive Agricultural Technologies in the Maya Area. Symposium paper presented at the 58th Annual Meeting of the Society for American Archaeology, St. Louis. 1993b. Rethinking the "New Orthodoxy": Interpreting Ancient Maya Agriculture and Environment. In Culture, Form, and Place: Essays in Cultural and Historical Geography, ed. K. Mathewson, pp. 57-88. Geoscience and Man, Vol. 32. Baton Rouge, Louisiana: Geoscience Publications, Louisiana State University.

1994. Personal communication.

Turner, B. L., II, and Harrison, P. D. 1978. Implications from Agriculture for Maya Prehistory. In Pre-Hispanic Maya Agriculture, ed. P. D. Harrison and B. L. Turner, II, pp. 337-373. Albuquerque: University of New Mexico Press.

_, and 1979. B. L. Turner and Peter D. Harrison Comment on William T. Sanders's Review of Pre-Hispanic Maya Agriculture. Reviews in Anthropology 6:544-555.

$\longrightarrow$, and —. 1981. Prehistoric Raised-Field Agriculture in the Maya Lowlands. Science 213:399-405.

, and —, eds. 1983. Pulltrouser Swamp: Ancient Maya Habitat, Agriculture, and Settlement in Northern Belize. Austin: University of Texas Press.

Turner, B. L, II, and Miksicek, C. H. 1984. Economic Plant Species Associated with Prehistoric Agriculture in the Maya Lowlands. Economic Botany 38:179-193.

Vasey, D. E. 1983. Plant Growth on Experimental Island Beds and Nitrogen Uptake from Surrounding Water. Agriculture, Ecosystems and Environment 10:15-22.

Vasey, D. E., Harris, D. R., Olson, G. W., Spriggs, M. J. T., and Turner, B. L., II. 1984. The Role of Standing Water and Water-Logged Soils in Raised-Field, Drained-Field and Island-Bed Agriculture. Singapore Journal of Tropical Geography 5:63-72.

Vaughan, H. H., Deevey, E. S., Jr., and Garrett-Jones, S. E. 1985. Pollen Stratigraphy of Two Cores from the Petén Lake District, with an Appendix on Two Deep-Water Cores. In Prehistoric Lowland Maya Environment and Subsistence Economy, ed. Mary Pohl, pp. 73-89. Cambridge: Harvard University Press.

Watts, W. A., and Bradbury, J. P. 1982. Paleoecological Studies at Lake Patzcuaro on the West-Central Mexican Plateau and at Chalco in the Basin of Mexico. Quaternary Research 17:56-70.

Weigand, P. E. 1974. The Ahualulco Site and the Shaft-Tomb Complex of the Etzatlan Area. In The Archaeology of West Mexico, ed. B. Bell, pp. 120-131. Ajijic, Jalisco: West Mexican Society for Advanced Study.

- 1991. Las chinampas Prehispanicas del occidente de Jalisco. El Occidental (newspaper, Guadalajara) 5 August.

. 1993. Large-Scale Hydraulic Works in Prehistoric Western Mesoamerica. In Economic As- 
pects of Water Management in the Prehispanic New World; Research in Economic Anthropology, supplement 7, ed. B. Isaacs and V. Scarborough, pp. 223-262. London: JAI Press.

West, R. C., ed. 1964. Handbook of Middle American Indians. Vol. 1, Natural Environment and Early Cultures. Austin: University of Texas Press.

West, R. C., and Armillas, P. 1950. Las chinampas de Mexico. Cuadernos Americanos 50:165-182.

White, S. E. 1981. Equilibrium Line Altitudes of Late Pleistocene and Recent Glaciers in Central Mexico. Geografiska Annaler 63A:241-249.

-1 1986. Quaternary Glacial Stratigraphy and Chronology of Mexico. Quaternary Science Reviews 5:201-205.

Wilken, G. C. 1969. Drained-Field Agriculture: An Intensive Farming System in Tlaxcala, Mexico. Geographical Review 59:215-241.

. 1970. The Ecology of Gathering in a Mexican Farming Region. Economic Botany 24:286-295.

—. 1971. Food-Producing Systems Available to the Ancient Maya. American Antiquity 36:432448.
1985. A Note on Buoyancy and Other Dubious Characteristics of the "Floating" Chinampas of Mexico. In Prehistoric Intensive Agriculture in the Tropics, ed. I. S. Farrington, pp. 31-48. Oxford: British Archaeological Reports.

. 1987. Good Farmers: Traditional Agricultural Resource Management in Mexico and Central America. Berkeley: University of California Press. Wilkerson, S. J. K. 1980. Man's Eighty Centuries in Veracruz. National Geographic 158:202-231.

. 1983. So Green and like a Garden: Intensive Agriculture in Ancient Veracruz. In Drained Field Agriculture in Central and South America, ed. J. P. Darch, pp. 55-90. Oxford: British Archaeological Reports.

Woods, W. I., and Fowler, M. L. 1989. Prehistoric and Historic Water Control in the Puebla-Tlaxcala Basin. Paper presented at the Conference of Latin Americanist Geographers, Querétero.

Submitted 4/93, Revised 4/94, Accepted 5/94.

Sluyter, Andrew. 1994. Intensive Wetland Agriculture in Mesoamerica: Space, Time, and Form. Annals of the Association of American Geographers 84(4):557-584. Abstract.

Geographers have led the effort to better understand Prehispanic, intensive wetland agriculture ("raised fields") in Mesoamerica. An overview of that literature provides the database for a subsequent spatial-temporal analysis and a resource for primary research. The analysis employs maps to identify changing relationships among distribution, hectareage, and morphometry in order to address wetland agriculture's role in the emergence of sedentism, urbanism, statism, and corollary environmental change; its interrelationships with other agroecosystems and ecological parameters; and its productivity and sustainability. The result is a modest benchmark in the research process which identifies significant variables, putative patterns, and several testable hypotheses, namely 1 ) that wherever social processes elicited dense population nucleations and hydrology was appropriate, farmers built wetland fields; 2) that the emergence of intensive wetland agriculture was ecologically interrelated with terracing, canal irrigation, and extensive agroecosystems; 3 ) that morphometric variation among wetland fields reflected contextual variables of hydrology, population density, taxation, and centralization of decision making; and 4) that intensive wetland agriculture in Mesoamerica was a productive and sustainable agroecosystem. Key Words: agroecosystems, intensive wetland agriculture, Mesoamerica, Prehispanic, raised fields. 